\title{
Compressive strength of masonry constructed with high strength concrete blocks
}

\section{Resistência a compressão da alvenaria estrutural com blocos de concreto de alta resistência}

E. S. FORTES a

ernestofortes@hotmail.com

G. A. PARSEKIAN a parsekian.ufscar@gmail.com

J. S. CAMACHO jsc@dec.feis.unesp.br

F. S. FONSECA ${ }^{c}$ fonseca@byu.edu

\begin{abstract}
Although the use of high strength concrete blocks for the construction of tall buildings is becoming common in Brazil, their mechanical properties and behavior are not fully understood. The literature shows a gap in experimental studies with the use of high strength concrete blocks, i.e., those with compressive strength greater than $16 \mathrm{MPa}$.

The work presented herein was conducted in order to study the behavior of high strength structural masonry. Therefore, the compressive strength and modulus of elasticity of concrete block walls tested under axial load were assessed. The specimens included grouted and ungrouted walls and walls with a mid-height bond beam; ungrouted walls were constructed with faceshell and full mortar bedding. The walls were built and tested in the laboratory of CESP and in the Structures Laboratory of the UNESP Civil Engineering Department in Ilha Solteira (NEPAE). Concrete blocks with nominal compressive strength of 16 (B1), 24 (B2) and 30 (B3) MPa were used. Ungrouted masonry walls had a height of $220 \mathrm{~cm}$ and a width of $120 \mathrm{~cm}$ while grouted masonry walls had a height of $220 \mathrm{~cm}$ and a width of $80 \mathrm{~cm}$. Traditional Portland cement, sand and lime mortar was used. The testing program included 36 blocks, 18 prisms, 9 ungrouted walls ( 6 with face-shell mortar bedding and 3 with full mortar bedding), 9 grouted masonry walls, and 12 ungrouted walls with a bond beam at mid-height.

The experimental results were used to determine the compressive strength ratio between masonry units, prisms and masonry walls. The analyses included assessing the cracking pattern, the mode of failure and the stress-strain curve of the masonry walls.

Tests results indicate that the prism-to-unit strength ratio varies according to the block strength; that face-shell mortar bedding is suitable for high strength concrete masonry; and that $20 \%$ resistance decrease for face-shell mortar bedding when compared with full mortar bedding is a conservative consideration. The results also show that using a bond beam at the mid-height of the wall does not lead to a compressive strength decreased but it changes the failure mode and the shape of the stress-strain curve. In addition, the results show that estimating $\mathrm{E}=800 \mathrm{fp}$ is conservative for ungrouted masonry walls but reasonably accurate for grouted masonry walls and that there is no reason to limit the value of E to a maximum value of $16 \mathrm{GPa}$. Furthermore, the results show that, for design purposes, a wall-to-prism strength ratio value of 0.7 may be used for high strength concrete masonry.
\end{abstract}

Keywords: structural masonry, concrete block, high strenght, compressive strenght, high-rise buildings.

\section{Resumo}

Ainda que 0 uso de blocos de concreto de alta resistência para a construção de edifícios altos esteja se tornando comum no brasil, as características e alguns aspectos do comportamento não são totalmente conhecidos. A literatura mostra uma lacuna em estudos experimentais com a utilização de blocos de concreto de alta resistências, acima de 16 MPa. 0 trabalho aqui apresentado foi realizado com o objetivo de estudar o comportamento da alvenaria estrutural de alta resistência. Para tanto foram estudadas a resistência a compressão e 0 modulo de elasticidade em paredes de blocos de concreto ensaiadas sob carregamento axial, divididas em paredes ocas, paredes grauteadas, paredes com cinta grauteada a meia altura e paredes com assentamento parcial e total. As paredes foram construídas e ensaiados no laboratório da CESP e no laboratório de Estruturas do Dep. De Engenharia Civil da UNPESP de Ilha Solteira (NEPAE). Foram utilizados blocos de concreto com valores nominais de resistência à compressão de 16 (B1), 24 (B2) e 30 (B3) MPa. As paredes ocas foram construídas com altura de $220 \mathrm{~cm}$ e largura de $120 \mathrm{~cm}$, enquanto as paredes grauteadas foram construídas com altura de $220 \mathrm{~cm}$ e largura de $80 \mathrm{~cm}$, utilizando argamassa tradicional de cimento, areia e cal. Foram ensaiados 36 blocos, 18 prismas, 9 paredes ocas (6 com argamassa apenas na lateral dos blocos e 3 com argamassa sobre toda a face desses), 12 paredes grauteadas, e 12 paredes ocas onde foi introduzida uma canaleta grauteada a meia altura.

A análise dos resultados experimentais possibilitou verificar a relação entre a resistência a compressão das unidades de alvenaria, dos prismas e das paredes de alvenaria. Foi também analisada a fissuração, modo de ruptura e curva tensão - deformação das alvenarias ensaiadas.

Através dos resultados dos ensaios verificou-se que o valor da relação de resistência prisma/bloco varia conforme a resistência do bloco; que o procedimento executivo com argamassa apenas na lateral é adequado para blocos de concreto de alta resistência, sendo conservadora a consideração de diminuição de resistência de $20 \%$ quando comparada com casos com argamassa disposta sobre toda a face dos blocos; que o uso de cinta grauteada à meia altura das paredes não levou a diminuição da resistência a compressão, mas alterou a forma de ruptura e a forma da curva tensão-deformação; que os módulos de elasticidade medidos nas paredes ensaidas foram sempre maiores que $800 \mathrm{fp}$ para paredes ocas e entre 688 e 848 fp para paredes grauteadas, não sendo verificado a necessidade de limitar E ao valor máximo de $16 \mathrm{GPa}$. Por último, foi verificado que o valor da relação de resistência parede/prisma igual a 0,7 pode ser adotado para blocos de concreto de alta resistência.

Palavras-chave: alvenaria estrutural, bloco de concreto, alta resistência, resistência a compressão, edifícios altos

Universidade Federal de Sao Carlos, Departamento de Engenharia Civil, São Carlos, SP, Brasil,

Universidade Estadual Paulista Julio de Mesquita e Filho, Departamento de Engenharia Civil, São Paulo, SP, Brasil;

Brigham Young University, Departamento de Engenharia Civil, Provo, UT, Estados Unidos da América.

Received: 23 Aug 2016 • Accepted: 21 Mar 2017 • Available Online: 11 Dec 2017 


\section{Introduction}

Structural design in masonry requires a clear understanding of the behavior of the mortar and unit assembled to resist different load conditions. The combination of blocks and mortar of different characteristics, changes significantly the behavior of structural masonry elements. In structures with these elements, the compressive strength of the masonry is the controlling mechanical property for the project. The compressive strength of masonry depends on several factors such as: mortar strength; unit strength; relative ratio between the mortar and unit strength; relationship between the height of the unit and the smaller horizontal dimension of the unit; orientation of the unit in relation to the direction of the load application; and the thickness of the mortar joint. The large number of factors, individually and combined, indicates, therefore, the complexity of making a precise evaluation of the masonry strength.

According to Parsekian et al. [1], masonry compressive strength depends on large-scale on the block type and to a lesser extent on the workforce, and yet to a lesser extent on the type of mortar. Hendry et al. [2] discuss more in deep the important factors affecting compressive strength of masonry. These factors are presented in Table 1.

Curtin et al. [3] simplify the analyses of masonry. by indicating that the characteristic resistance of masonry to compressive loads depends on the characteristic strength of the unit; on the specified mortar if the masonry is mortared; on the units' shape; on the thickness of the mortar joints; and on the workmanship.

According to ABNT NBR 15961-1 [4], the characteristic compressive strength of the masonry, $\mathrm{f}_{\mathrm{k}}$. should be determined based on testing of walls (ABNT NBR 8949[5]) or be estimated as $70 \%$ of the characteristic strength of the masonry prism, $\mathrm{f}_{\mathrm{pk}}$, or $85 \%$ of the characteristic strength of small walls, $\mathrm{f}_{\mathrm{pok}}$. These values are determined using gross area.

The EUROCODE 6 [10] gives two equations to determine the masonry compressive strength: one for regular 10-mm mortar joint and one for 3-mm or less thin mortar joint. These formulations consider the compressive strength of the block, the average compressive strength of the mortar, the mortar joint thickness and a factor $\mathrm{k}$ that depends on the type of block and mortar:

$f_{k}=k f_{b}^{0.7} f_{m}^{0.3}$ - Equation 1 - masonry with 10-mm mortar joint; $f_{k}=k f_{b}^{0.85}$ - Equation 2 - masonry with $3 \mathrm{~mm}$ or less thin mortar joint. with $\mathrm{k}=0.5$ for hollow concrete block.
Masonry has a brittle behavior, is non-homogeneous and anisotropic, and is composed of two materials with very different mechanical properties: the more rigid block and the relatively deformable mortar; as needed. grout and reinforcement are added. Masonry has very low tensile strength because the different materials are distributed at regular intervals, and the connection between them is weak. Therefore. unreinforced masonry, which is built extensively, should be expected to mainly resist compression loads.

Masonry under compression experience three main modes of rupture. depending on the relationship between the compressive strength of the mortar and that of the block:

a) When the mortar is very weak compared to the block. the masonry capacity is limited by the strength of the mortar. which usually fails by crushing;

b) When the mortar has a moderate strength, the masonry capacity is determined by a combination of the compression and tension strength of the block, which usually fails by lateral tension;

c) When the mortar is stronger than the block, masonry capacity is limited by the block compressive strength.

The more the masonry gets closer to failure mode "c". the more brittle and explosive the failure is. The preferred failure mode is more "b". which is a middle ground allowing the masonry to reach an adequate compressive strength without experiencing an extremely brittle failure. in addition to reducing the potential for crushing if the mortar and cracking at the mortar joint. For typical masonry. Parsekian et al. [1] recommend that the resistance of mortar is specified between 70 to $150 \%$ of the strength of the block (gross area).

During compressive testing of masonry walls constructed with high-strength blocks and with mortar with moderate, aproximatelly strength between 70 and $150 \%$ of that of the block, the mortar has a greater tendency to expand laterally in relation to blocks, because the later has a higher stiffness. However, the mortar is confined laterally on the block-mortar interface; therefore. shear stresses develop on the interface block-mortar. Thus, the mortar in the mortar joint is under a triaxial state of stress while the blocks experience bilateral tension. This stress state leads to vertical cracks in the blocks and eventual rupture of the wall (McNary and Abrams [11]; Atkinson and Noland [12]; Drysdale et al. [13]).

On Table 2 is summarized some experimental results for masonry compressive strength. Unless otherwise specified, the data in this table refer to strength in the gross area, $100 \times 50 \mathrm{~mm}$ cylindrical mortar specimens, two-block prisms, and prisms and walls not grouted. Cavalheiro and Gomes [14] summarized and analyzed

\section{Table 1}

Variables that affect masonry strength

\begin{tabular}{|c|c|c|}
\hline Block properties & Mortar properties & Masonry \\
\hline Strength & Strength & Connection \\
\hline Type and geometry & Mix design & Concentrated stress \\
\hline Height/thickness ratio & Water/cement ratio & - \\
\hline Absorption & Water retentivity & - \\
\hline- & $\begin{array}{c}\text { Elastic properties compared to block } \\
\text { elastic properties }\end{array}$ \\
\hline
\end{tabular}


multiple tests of blocks, prisms and walls of concrete blocks (largest strength $=10 \mathrm{MPa}$ ), with strength ratios given in Table 3 .

Other researchers, (ROMAGNA [19]; MAURÍCIO [20]) have conducted compressive strength tests, but with low and moderate strength blocks.
Fortes [21] conducted an experimental testing program with concrete blocks from, 4 to $35 \mathrm{MPa}$, and determined the block and prism behavior. Figure 1 shows the results of the prism/block strength ratio for several strengths. As shown, the prism/block strength ratio decreases with increasing block strengths.

Table 2

Brazilian experimental research results on masonry strength (MPa)

\begin{tabular}{|c|c|c|c|c|c|c|c|}
\hline \multirow{11}{*}{ 点 } & & $f_{b}$ & $f_{a}$ & $f_{p}$ & $f_{g k}$ & $f_{p a r}$ & Note \\
\hline & \multirow{10}{*}{ 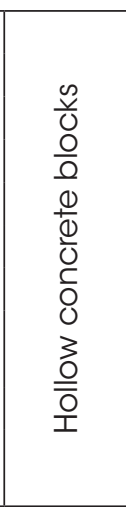 } & 7.90 & - & 6.40 & - & 5.10 & - \\
\hline & & 10.60 & 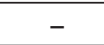 & 9.30 & 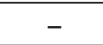 & 6.40 & - \\
\hline & & 13.30 & $\begin{array}{ll}- \\
\end{array}$ & 9.80 & - & 8.30 & - \\
\hline & & 7.90 & - & 6.40 & - & 8.10 & \multirow{3}{*}{ Fully grouted } \\
\hline & & 10.60 & - & 9.30 & $\begin{array}{lll}- \\
-\end{array}$ & 9.90 & \\
\hline & & 13.30 & - & 9.80 & - & 11.10 & \\
\hline & & 7.90 & - & 6.40 & - & 10.00 & \multirow{2}{*}{$\begin{array}{l}\text { Fully grouted } \\
0.2 \% \text { of } \\
\text { reinforcement }\end{array}$} \\
\hline & & 10.60 & - & 9.30 & - & 10.80 & \\
\hline & & 7.90 & - & 6.40 & - & 9.20 & \multirow{2}{*}{$\begin{array}{l}\text { Fully grouted } \\
0.3 \% \text { of } \\
\text { reinforcement }\end{array}$} \\
\hline & & 10.60 & - & 9.30 & - & 12.30 & \\
\hline & & $f_{b}$ & $f_{a}$ & $f_{p}$ & $f_{g k}$ & $f_{p a r}$ & Note \\
\hline \multirow{6}{*}{ 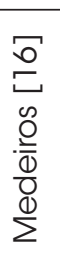 } & \multirow{6}{*}{ 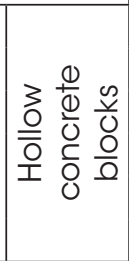 } & 8.40 & 4.55 & - & - & 4.28 & - \\
\hline & & 8.40 & 5.89 & - & - & 4.64 & - \\
\hline & & 10.80 & 4.55 & - & - & 4.83 & - \\
\hline & & 10.80 & 5.89 & - & - & 5.26 & - \\
\hline & & 14.90 & 4.55 & - & - & 4.97 & - \\
\hline & & 14.90 & 5.89 & - & - & 6.52 & - \\
\hline & & $f_{b}$ & $f_{a}$ & $f_{p}$ & $f_{g k}$ & $f_{p a r}$ & Note \\
\hline \multirow{8}{*}{$\begin{array}{l}\Sigma \\
\Xi \\
0 \\
0 \\
0 \\
\frac{1}{0} \\
\sum\end{array}$} & \multirow{8}{*}{$\begin{array}{l}\frac{0}{0} \\
\text { O } \\
0 \\
\frac{0}{0} \\
\frac{0}{3} \\
\text { O } \\
\overline{\overline{0}}\end{array}$} & 22.89 & 6.47 & - & - & - & \multirow{8}{*}{$\begin{array}{l}\text { 3-block high } \\
\text { prism; full bed } \\
\text { mortar joints; } \\
\text { fully grouted } \\
\text { when grout } \\
\text { strength is } \\
\text { presented }\end{array}$} \\
\hline & & 22.89 & 6.68 & 12.28 & 49.87 & - & \\
\hline & & 22.89 & 7.00 & 14.66 & 28.32 & - & \\
\hline & & 22.89 & 6.52 & 17.94 & 13.94 & - & \\
\hline & & 22.89 & 19.86 & 12.56 & - & - & \\
\hline & & 22.89 & 19.09 & 20.81 & 49.57 & - & \\
\hline & & 22.89 & 19.78 & 19.53 & 25.08 & - & \\
\hline & & 22.89 & 21.15 & 21.33 & 12.37 & - & \\
\hline \multirow{8}{*}{ 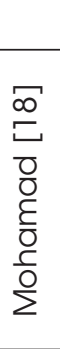 } & & $f_{b}$ & $f_{a}$ & $f_{p}$ & $f_{g k}$ & $f_{\text {par }}$ & Note \\
\hline & \multirow{7}{*}{$\begin{array}{l}\frac{0}{0} \\
\frac{0}{0} \\
\frac{0}{0} \\
0 \\
0 \\
3 \\
0 \\
\frac{0}{0} \\
\frac{0}{1}\end{array}$} & 10.70 & 19.90 & 10.56 & - & - & \multirow{7}{*}{$\begin{array}{l}\text { 3-block high } \\
\text { prism; full bed } \\
\text { mortar joints }\end{array}$} \\
\hline & & 10.70 & 8.63 & 8.60 & - & - & \\
\hline & & 10.70 & 4.20 & 8.17 & - & - & \\
\hline & & 10.70 & 2.28 & 7.54 & - & - & \\
\hline & & 15.70 & 19.90 & 11.70 & - & - & \\
\hline & & 15.70 & 8.63 & 10.80 & - & - & \\
\hline & & 15.70 & 4.20 & 8.84 & - & - & \\
\hline & & $f_{b}$ & $f_{a}$ & $f_{p}$ & $f_{g k}$ & $f_{\text {par }}$ & Note \\
\hline \multirow{2}{*}{ 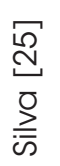 } & \multirow{2}{*}{ 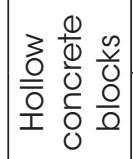 } & 11.8 & 5 & 10.1 & - & 8.56 & \multirow{2}{*}{$\begin{array}{l}\text { 3-block high } \\
\text { prism; full bed } \\
\text { mortar joints }\end{array}$} \\
\hline & & 22 & 5 & 14.4 & - & 8.16 & \\
\hline
\end{tabular}


Table 3

Concrete block results ( $\mathrm{f}_{\mathrm{bk}}$ up to $10 \mathrm{MPa}$ )

\begin{tabular}{|c|c|c|c|c|}
\hline \multirow{2}{*}{66 walls } & \multicolumn{4}{|c|}{ Strength ratio } \\
\cline { 2 - 5 } & $\mathbf{f}_{\mathrm{pa}} / \mathbf{f}_{\mathrm{a}}$ & $\mathbf{f}_{\mathrm{pa}} / \mathbf{f}_{\mathrm{ppa}}$ & $\mathbf{f}_{\mathrm{pa}} / \mathbf{f}_{\mathrm{p}}$ & $\mathbf{f}_{\mathrm{p}} / \mathbf{f}_{\mathrm{b}}$ \\
\hline Average & 0.51 & 1.00 & 0.69 & 0.80 \\
\hline Standard deviation & 0.08 & 0.12 & 0.13 & 0.07 \\
\hline Coefficient of variation & 0.16 & 0.12 & 0.19 & 0.09 \\
\hline Source: Cavalheiro \& Gomes [14] & \multicolumn{4}{|l}{} \\
\hline
\end{tabular}

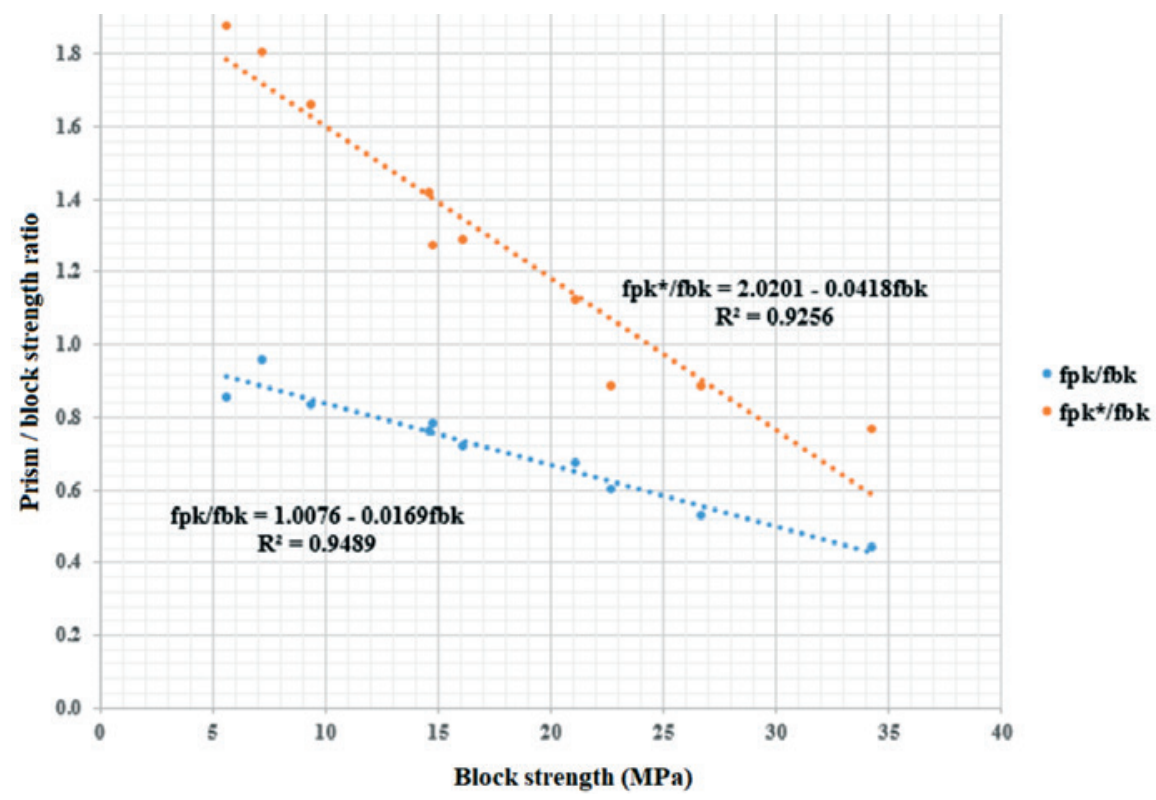

\section{Figure 1}

Prism / block strength ratio

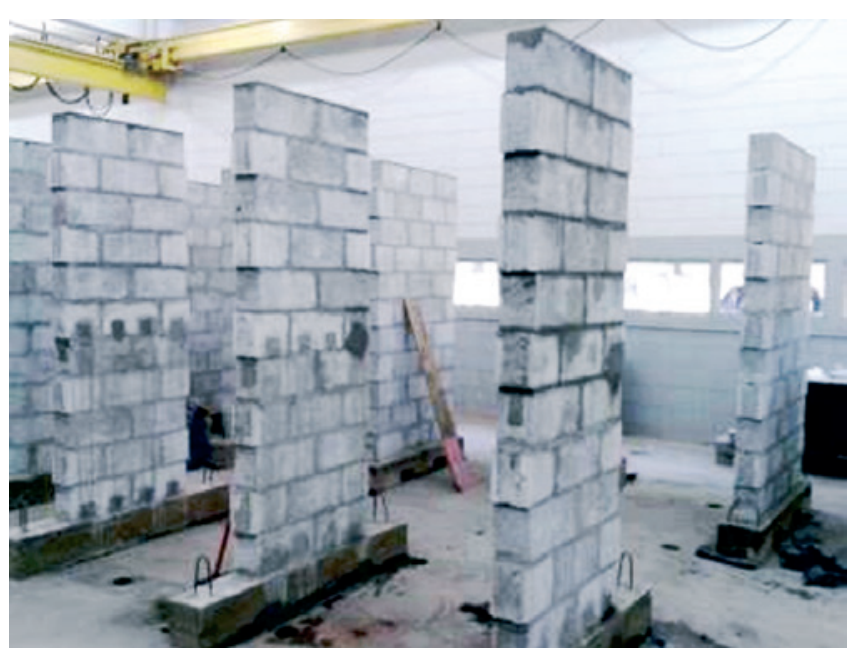

Figure 2

Wall before testing
The literature shows that a prism/block strength ratio equal to 0.80 can be assumed for 4-MPa blocks, but that ratio diminishes to 0.5 or less for $30-\mathrm{MPa}$ blocks, these strengths being determined using gross area. In the case of the wall testing, conducted with blocks up to $14 \mathrm{MPa}$, values above 0.7 for the wall/prism strength ratio are reported. There are no reports of wall testing with block with strengths higher than $14 \mathrm{MPa}$, except for one case with tests of walls built with 22-MPa block and with a weak mortar, below the recommended strength. Considering the large amount of tall buildings currently being built in Brazil and the that literature showed a lack of research on high-strength concrete blocks. over $14 \mathrm{MPa}$. the research herein presented is fully justified.

\subsection{Justification}

The objective of the study presented herein is to assess parameters and characteristics of masonry walls built with high-strength concrete blocks (of 18 to $34 \mathrm{MPa}$ when considering the gross area). The use of these blocks is not common anywhere else in the world. and today Brazil is one of the few countries where there are 
Table 4

Grouted walls with mid-height beam results

\begin{tabular}{|c|c|c|c|c|c|c|c|}
\hline Nome & Mid-beam & $\begin{array}{l}\text { Full or } \\
\text { faceshell } \\
\text { mortar }\end{array}$ & $\begin{array}{c}\text { Hollow or } \\
\text { grouted }\end{array}$ & $f_{b k}$ & $f_{a}$ & $\mathbf{f}_{\mathrm{gk}}$ & $\begin{array}{c}\# \\
\text { specimens }\end{array}$ \\
\hline B1-O-AT-CT & Yes & Full & Hollow & B1 & A1 & G1 & 3 \\
\hline B1-O-AP & No & Face & Hollow & B1 & A1 & - & 3 \\
\hline B1-G-AT-CT & Yes & Full & Grouted & B1 & A1 & G1 & 3 \\
\hline B2-O-AT-CT & Yes & Full & Hollow & B2 & $\mathrm{A} 2$ & G2 & 3 \\
\hline B2-O-AP & No & Face & Hollow & B2 & $\mathrm{A} 2$ & - & 3 \\
\hline B2-G-AT-CT & Yes & Full & Grouted & B2 & A2 & G2 & 3 \\
\hline B3-O-AT-CT & Yes & Full & Hollow & B3 & A3 & - & 3 \\
\hline B3-O-AT & No & Full & Hollow & B3 & A3 & - & 3 \\
\hline B3-G-AP & No & Face & Hollow & B3 & A3 & - & 3 \\
\hline B3-G-AT-CT & Yes & Full & Grouted & B3 & A3 & G3 & 3 \\
\hline
\end{tabular}

current applications with these materials, herein that are called highstrength concrete blocks. Even though their use is common in Brazil, the characteristics and some aspects of their behavior are not fully known. Several buildings are constructed with high-strength concrete blocks, but the parameters for assessing their structural walls properties are based on strength ratios obtained from blocks with significant lower strength. Results of tests that allow to correlate the strength of concrete block, prism and wall for the high strength values reported herein are, as far as we know, unique. The research reported herein expands the knowledge and state-of-the-art.

\section{Materials and experimental program}

Thirty masonry walls. shown in Figure 2, including hollow and grouted walls, walls with or without an intermediate grouted bond beam, and walls fully and face-shell mortar bedding were tested under compression load.

The following elements were tested:

- Axial compression tests of masonry walls with 16, 24 and 30MPa nominal capacity blocks:

- Hollow, with an intermediate grouted bond beam at half wall height (bond beam blocks had strength of $6 \mathrm{MPa}$ );

- Hollow, with face-shell mortar bedding;

- Hollow, with full mortar bedding;

- Grouted, with an intermediate grouted bond beam at half wall height;
Axial compression tests of prisms and concrete masonry blocks of 18,24 and $34 \mathrm{MPa}$.

Axial compression tests of mortar and grout specimens.

Table 4 summarizes the characteristics and number of wall tests performed.

\subsection{Mortar}

Three mortar mixes were used to build the walls. The compressive strength of the mortars was determined according to the resistance of the blocks. Mortar mix proportions were those used by Fortes [21], and, by weight, they were equal to $1: 0.42: 4.25 ; 1: 0.21: 3.40$ and 1:0.21:2.98, as shown in Table 5. Figure 3 shows the molding and the mortar specimens.

Portland cement type CP II-Z-32, hydrated lime and sand, were used and their average densities were determined during this research. For every mortar mix proportion, six specimens were molded and tested to control the production process.

\subsection{Grout}

For the walls and to fill the intermediate bond beam. the admixture "dry d1 c compact", tested by Fortes [21], was used in the grout mix to reduce grout shrinkage and minimize the separation at the block and grout interface. This admixture is a powdered inorganic product, free from chlorides and other harmful components. It is a

\section{Table 5}

Mortar characterization

\begin{tabular}{|c|c|c|c|c|}
\hline Name & $\begin{array}{c}\text { Mix proportion } \\
\text { by volume }\end{array}$ & $\begin{array}{c}\text { Mix proportion } \\
\text { by weight }\end{array}$ & w/c & $\begin{array}{c}\text { Nominal strength } \\
\text { (MPa) }\end{array}$ \\
\hline$A_{1}$ & $1: 1.0: 5.0$ & $1: 0.42: 4.25$ & 1.05 & 12 \\
\hline$A_{2}$ & $1: 0.5: 4.0$ & $1: 0.21: 3.40$ & 0.86 & 18 \\
\hline$A_{3}$ & $1: 0.5: 3.5$ & $1: 0.21: 2.98$ & 0.77 & 24 \\
\hline
\end{tabular}



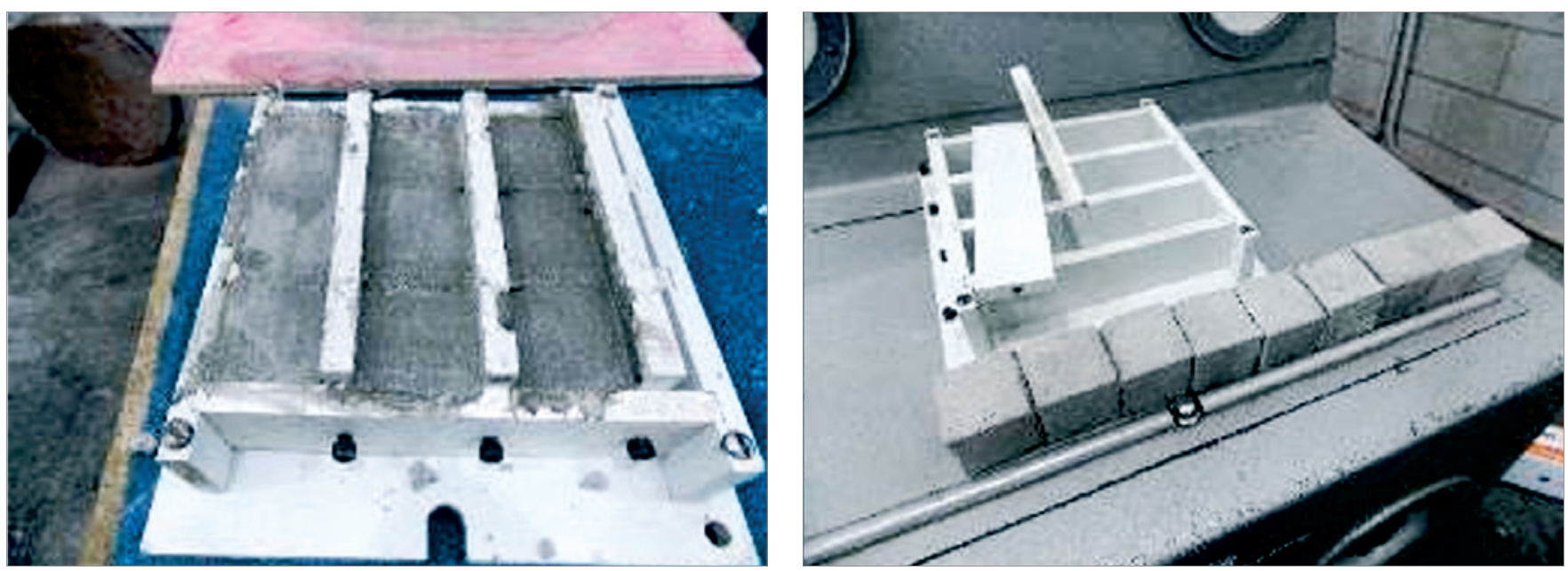

\section{Figure 3}

Prismatic mortar molding

\section{Table 6}

Grout characterization

\begin{tabular}{|c|c|c|c|c|}
\hline Name & $\begin{array}{c}\text { Mix proportion } \\
\text { by volume }\end{array}$ & $\begin{array}{c}\text { Mix proportion } \\
\text { by weight }\end{array}$ & w/c & $\begin{array}{c}\text { Nominal strength } \\
\text { (MPa) }\end{array}$ \\
\hline$G_{1}$ & $1: 0.1: 0.009: 1.6: 1.8$ & $1: 0.06: 0.01: 1.60: 1.80$ & 0.68 & 25 \\
\hline$G_{2}$ & $1: 0.1: 0.009: 1.4: 1.6$ & $1: 0.06: 0.01: 1.98: 2.02$ & 0.58 & 30 \\
\hline$G_{3}$ & $1: 0.1: 0.009: 1.0: 1.3$ & $1: 0.06: 0.01: 1.42: 1.64$ & 0.45 & 40 \\
\hline
\end{tabular}

heat-treated calcium oxide admixture with a selected specific granulometry and with expansive property. The expansive property induces decrease of porosity and reduction of permeability, an increase in compressive strength, and greater adherence between elements.

Three distinct grout strengths were used according to the block type, with mix proportions being those presented in Fortes
[21]. The mix proportion, by mass, were 1:0.06:0.01:1.60:1.80; 1:0.06:0.01:1.98:2.02; and 1:0.06:0.01:1.42:1.64 (cement: lime: admixture: sand: gravel); with nominal compression strengths, equal to $25\left(G_{1}\right) .30\left(G_{2}\right)$ and $40\left(G_{3}\right)$ MPa. Table 6 gives the denominations for each mix and summarizes, the mass and volume of the mix and the expected strength. Figure 4 shows the grout specimens and walls grouting procedure.
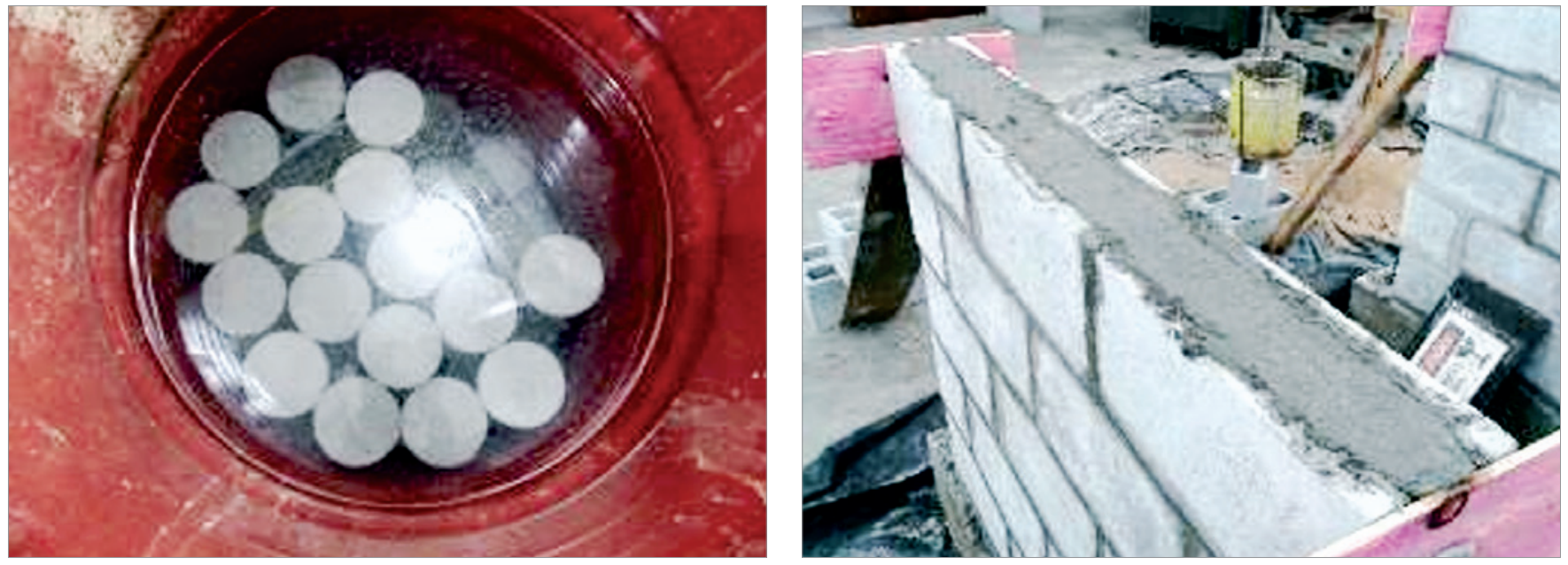

\section{Figure 4}

Grout specimens and grouted mid-height bond beam 

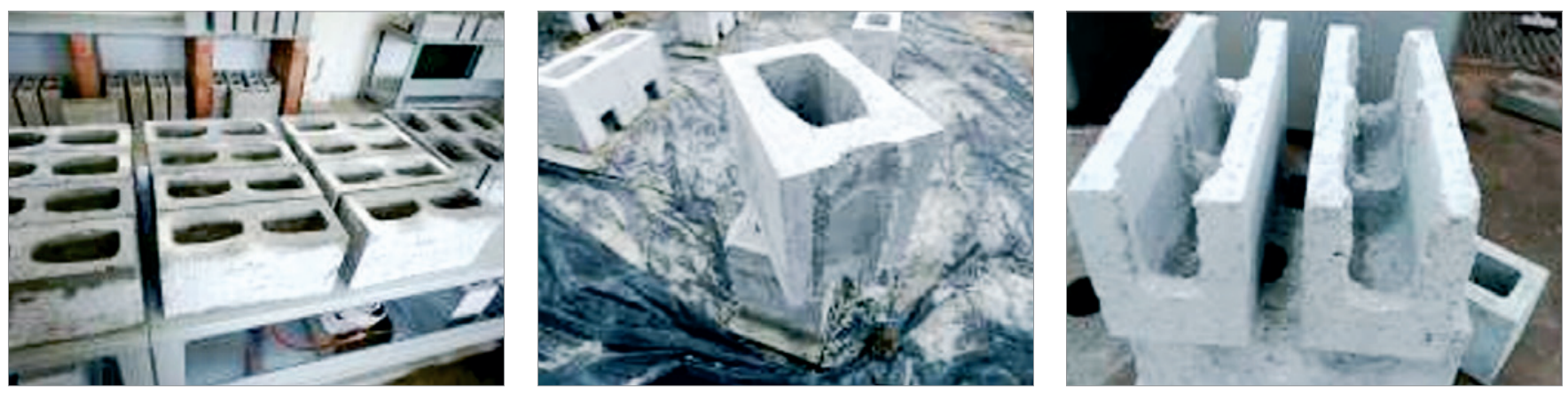

Figure 5

Standard concrete block, cut half-block; bond-beam block

\subsection{Block}

High-strength concrete blocks from the same supplier, complying with NBR 6136 [22] standard, of uniform geometry, and of nominal strengths of 16.24 and $30 \mathrm{MPa}$. called respectively of $\mathrm{B}_{1}$. $\mathrm{B}_{2}$ and $\mathrm{B}_{3}$ were used. For each block type, twelve blocks were tested to determine their compressive strength. The samples did not have cracks, deformities, or irregularities at the edges. Bond beam blocks, provided by the same manufacturer, but with nominal strength of 6 $\mathrm{MPa}$, were used in the construction of the intermediary bond beam regardless of the type of blocks used on the walls. Whole blocks were cut to be used as half blocks. Figure 5 shows the whole block, the block cut in half, and the bond-beam block.

\subsection{Construction of the prisms and walls}

Hollow and grouted prisms were built as specified by the Brazilian standard ABNT NBR 15961-2 [23]. The blocks, mortar and grout were combined for assembling prisms. Each prism was built with two stacked blocks and one mortar joint. Figure 6 shows one hollow and one grouted prism. The construction of the prisms closely followed the ABNT NBR 15961-2[23] requirements, and the same mason built all specimens.

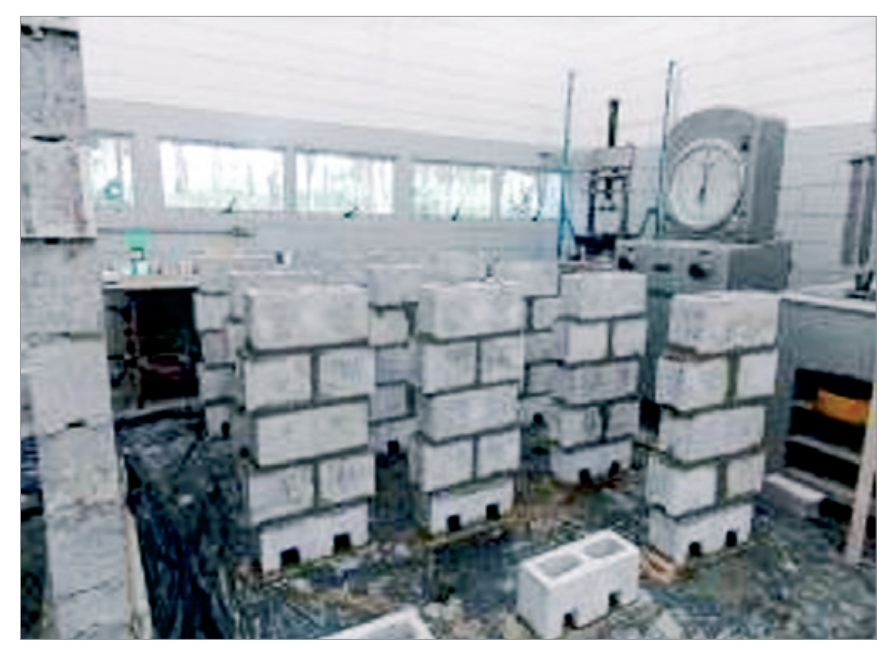

Figure 6

Hollow and grouted prism
The prisms were grouted after approximately 24 hours of their construction. Before grouting, mortar protrusions and droppings were removed from the prisms cells and each prism was wet. The grout was poured in two layers and consolidated with 12 rodding per layer as per ABNT NBR 15961-2[23]. After completing the grouting, the grout surface was leveled and smoothed with a trowel and immediately covered with an impermeable plastic film.

The construction of the walls followed the same procedure. Figure 7 to Figure 13 show the construction procedure sequence.

\subsection{Blocks, mortar and grout}

For each block strength, twelve blocks were tested as per ABNT NBR 12118 [6]. Block testing was done the same day of walls testing. The average compression strength of mortars was specified as $70 \%$ of the block compressive strength as peer ABNT NBR 15961-2 [23]. Mix proportions were the same as those reported in Fortes [21]. Six grout specimens and six mortar specimens were molded and tested for each group of walls. Grout testing followed ABNT NBR 5739 [24] specifications. The top and bottom surfaces of the specimens were ground prior to testing at 28-day age.

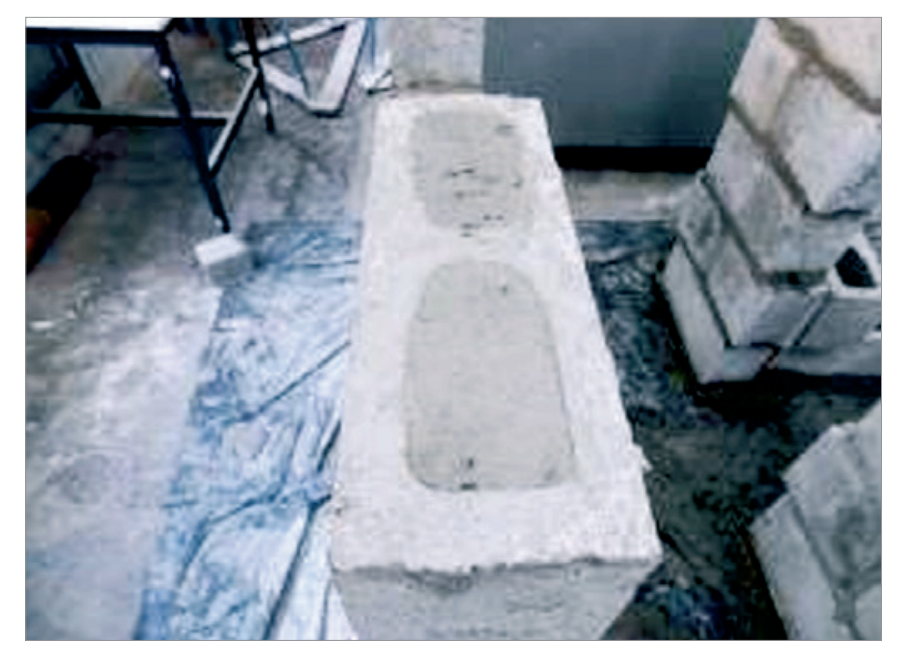



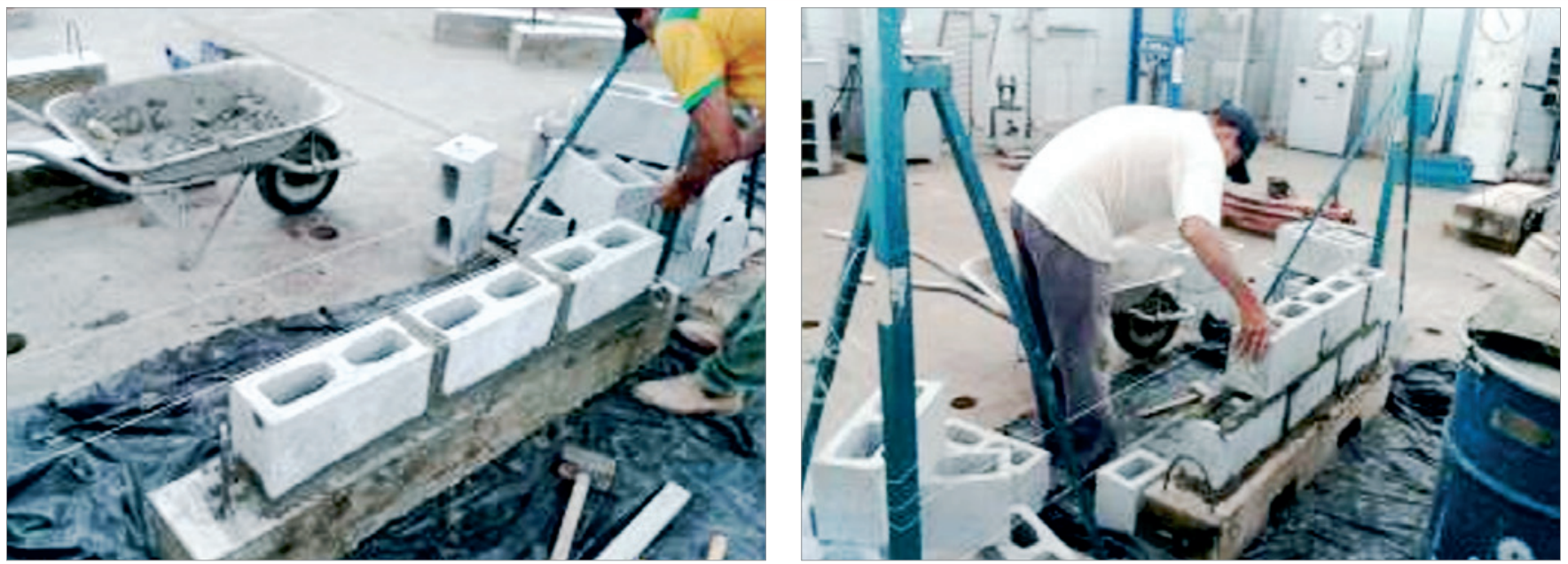

Figure 7

Corner gauge to aid wall construction
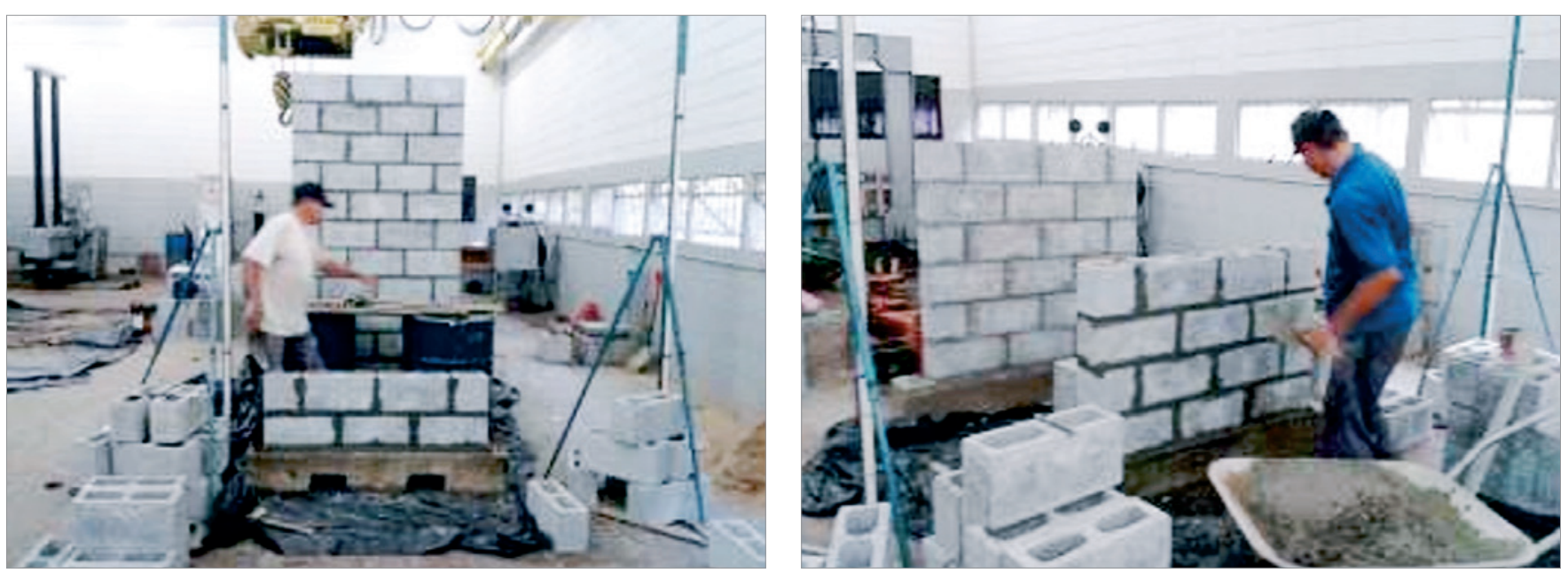

Figure 8

Wall construction sequence

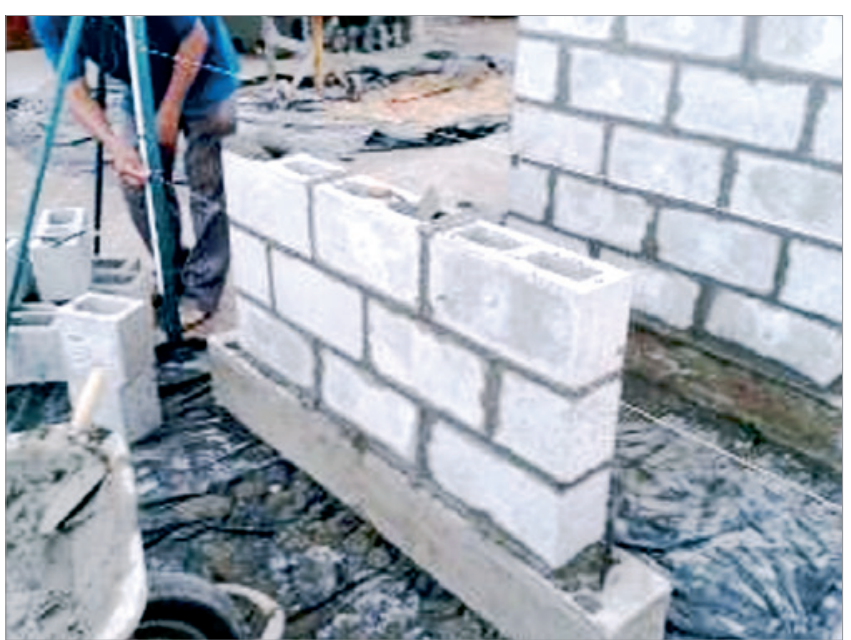

Figure 9

Hollow wall construction

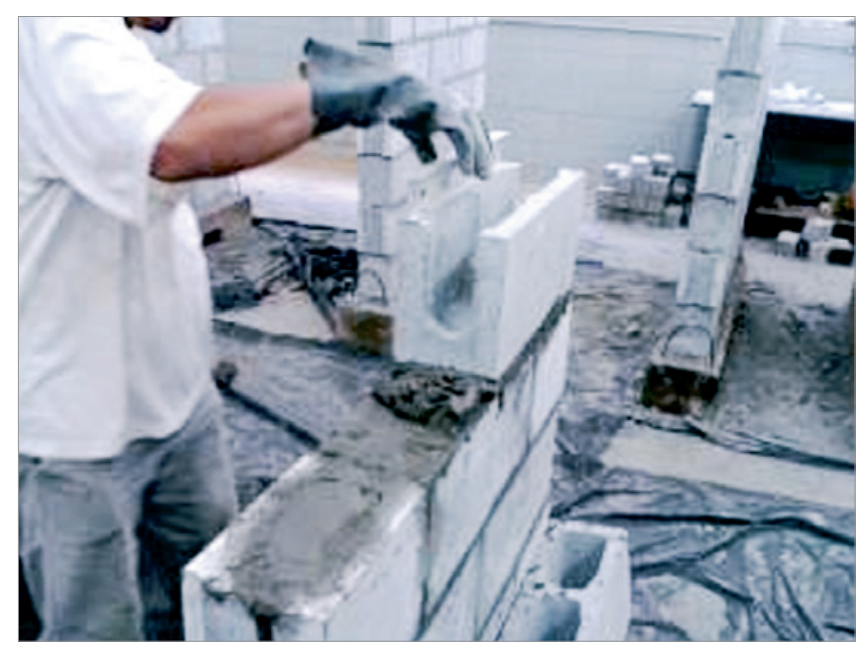

Figure 10

Mid-height bond beam laying 


\subsection{Prism}

Following the specifications of ABNT NBR 15961-2 [23], 18 hollow prisms and 18 grouted prisms were constructed and tested. The prisms were capped with cement paste as per ABNT NBR 15961$2[23]$. Tests were conducted using a $2000-\mathrm{kN}$ testing machine and the prisms were loaded at $0.05 \pm 0.01 \mathrm{MPa}$ per second.

\subsection{Wall configuration}

The wall testing was divided into three groups according to the blocks strength. In the first group, twelve walls were built with 30-MPa nominal strength blocks $\left(B_{3}\right)$ : three hollow walls with full bed mortar joints, three hollow walls with face-shell mortar joints, three walls with full bed mortar joints with a mid-height bond beam, and three walls fully grouted and with a mid-height bond beam. In the second group, nine walls were built with 24-MPa nominal

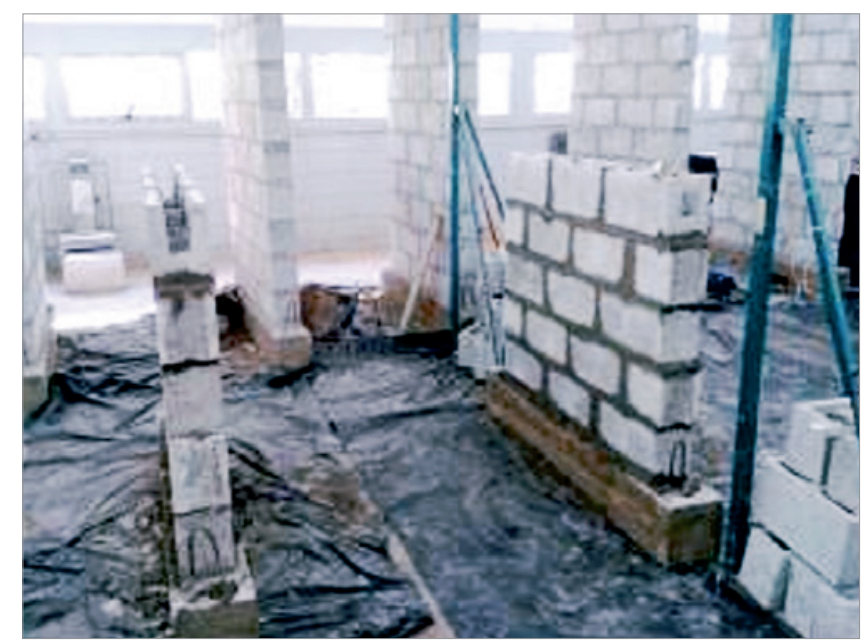

\section{Figure 11}

Wall with mid-height bond beam

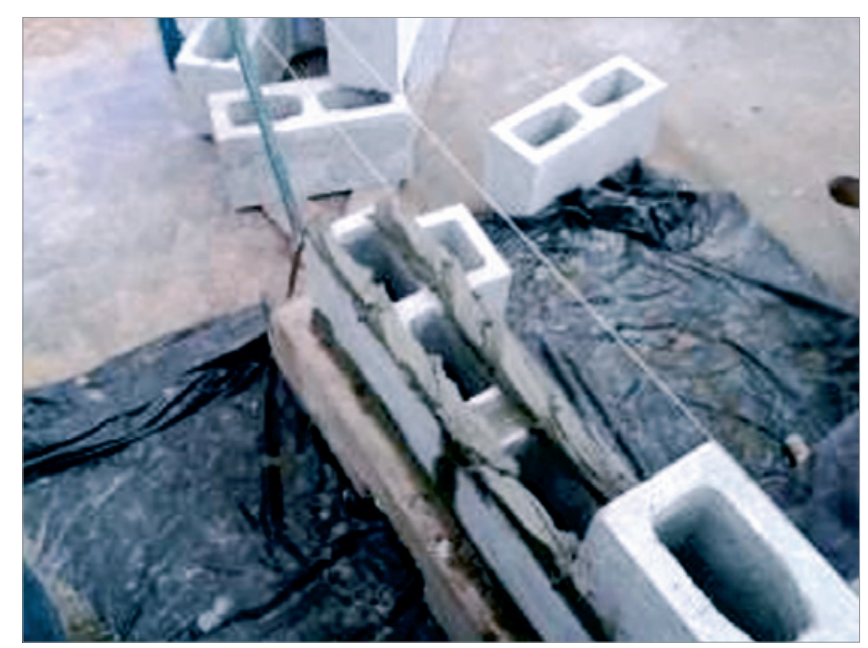

Figure 13

Face-shell bed mortar joint wall construction strength blocks $\left(B_{2}\right)$ : three hollow walls with full bed mortar joints and with a mid-height bond beam, three hollow walls with face-shell mortar joints, and three walls fully grouted with a mid-height bond beam. In the third group, nine walls were built with 16-MPa nominal strength blocks $\left(B_{1}\right)$ : three hollow walls with full bed mortar joints with a midheight bond beam, three hollow walls with face-shell mortar joints, and three walls fully grouted with a mid-height bond beam.

The walls were unreinforced except that a horizontal steel $10-\mathrm{mm}$ rebar was used in the mid-height bond beams. The ungrouted walls were $220-\mathrm{cm}$ high and $120-\mathrm{cm}$ wide while the grouted walls were 220 $\mathrm{cm}$ high and $80-\mathrm{cm}$ wide. due to load capacity of the testing machine. Regular cement-lime-sand mortar was used in the walls and prisms construction. The mortar was designed to have a 28-day compressive strength equal to $70 \%$ of the strength of the units, considering the gross area.

The grout used was designed to have a compressive strength at 28 days equal to $40\left(G_{3}\right), 30\left(G_{2}\right)$, and $25\left(G_{1}\right) M P a$, respectively

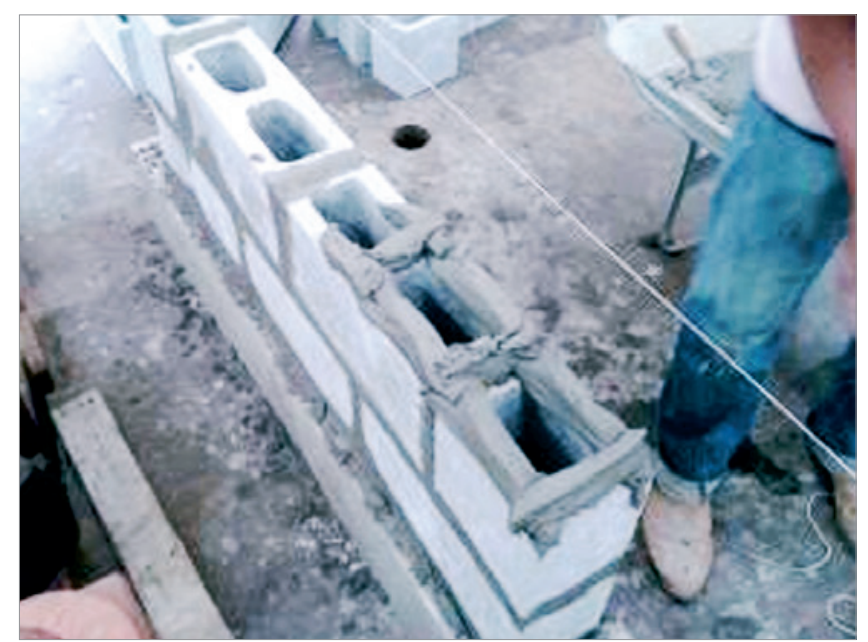

Figure 12

Full bed mortar joint wall construction

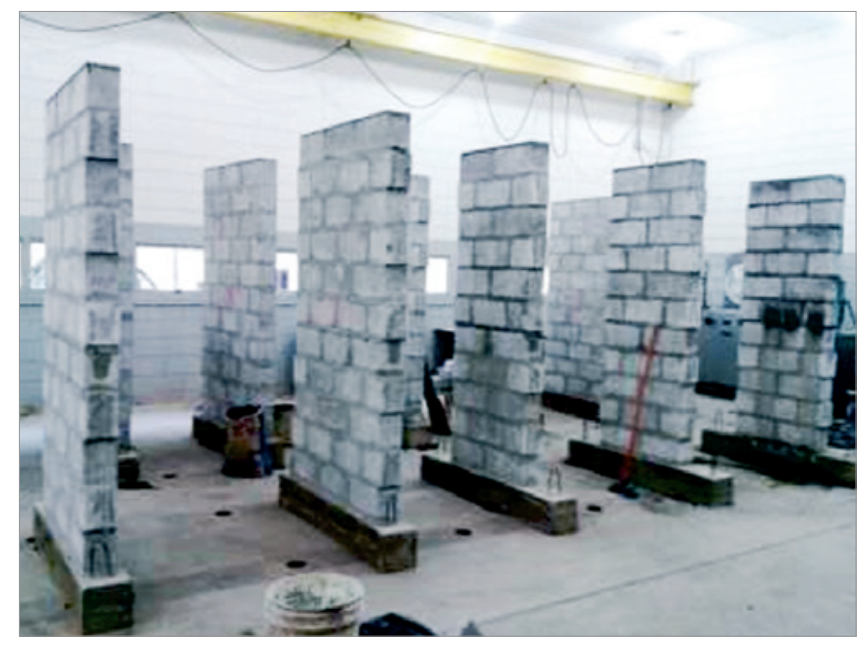

Figure 14

Walls before testing 


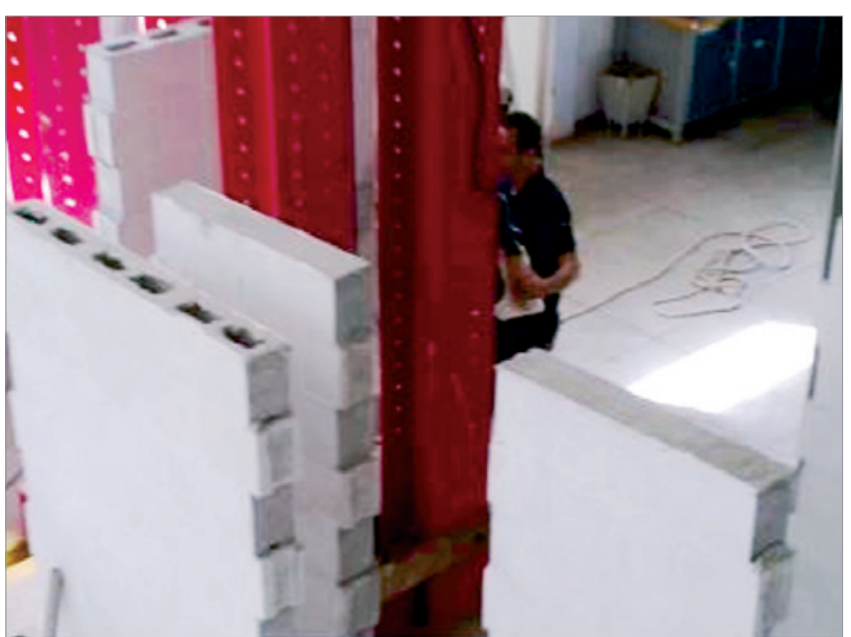

\section{Figure 15}

Walls capped with mortar

for the walls built with 30-MPa $\left(\mathrm{B}_{3}\right)$, 24-MPa $\left(\mathrm{B}_{2}\right)$, and 16-MPa $\left(\mathrm{B}_{1}\right)$ units. To reduce grout shrinkage and possible debounding at the grout and block shell interface, a shrinkage compensating admixture was added to the grout mix. For each wall group, twelve con-

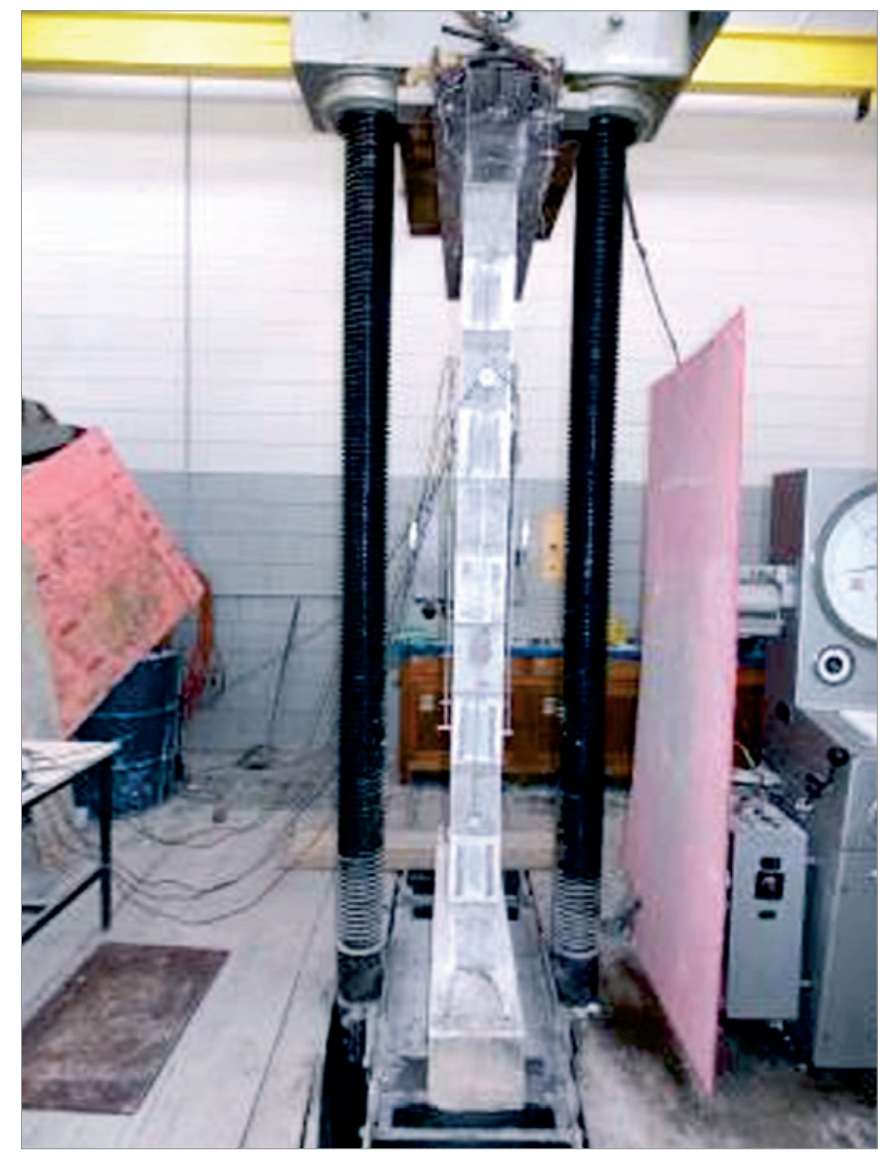

Figure 16

Walls testing. Group 1 e 2 crete blocks, six hollow prisms, and six grouted prisms were tested at the same time of the walls testing.

To differentiate the walls, a system with the following letter were used: Par-B-O-G-AT-AP-CT. The letters "Par" refers to the wall itself, the letter $B$ refers to the type of block used, and the letters $O$ and $G$ refer to hollow wall or grouted wall, respectively. The letters AT and AP are related to full bed mortar joint and face-shell mortar joint, respectively. Finally, the letters CT refer to the presence of the mid-height bond beam. To help better observe crack formation and propagation, all walls were white washed. Figure 14 shows some walls ready to be tested.

\subsection{Capping}

The walls were capped with mortar as shown in Figure 15 as per NBR 8949 [5] specifications. The mortar mix proportioning used was 1:0.5:2.0 (cement. lime and sand) designed to obtain a mortar strength higher than that of the blocks. The blocks were capped with a hardboard as described in Fortes [21] and the prisms were capped with cement paste.

\subsection{Test configuration and instrumentation}

A hydraulic 500-ton capacity (5000 kN) analog compression machine was used for testing Groups 1 and 2 walls, as shown in Figure 16.

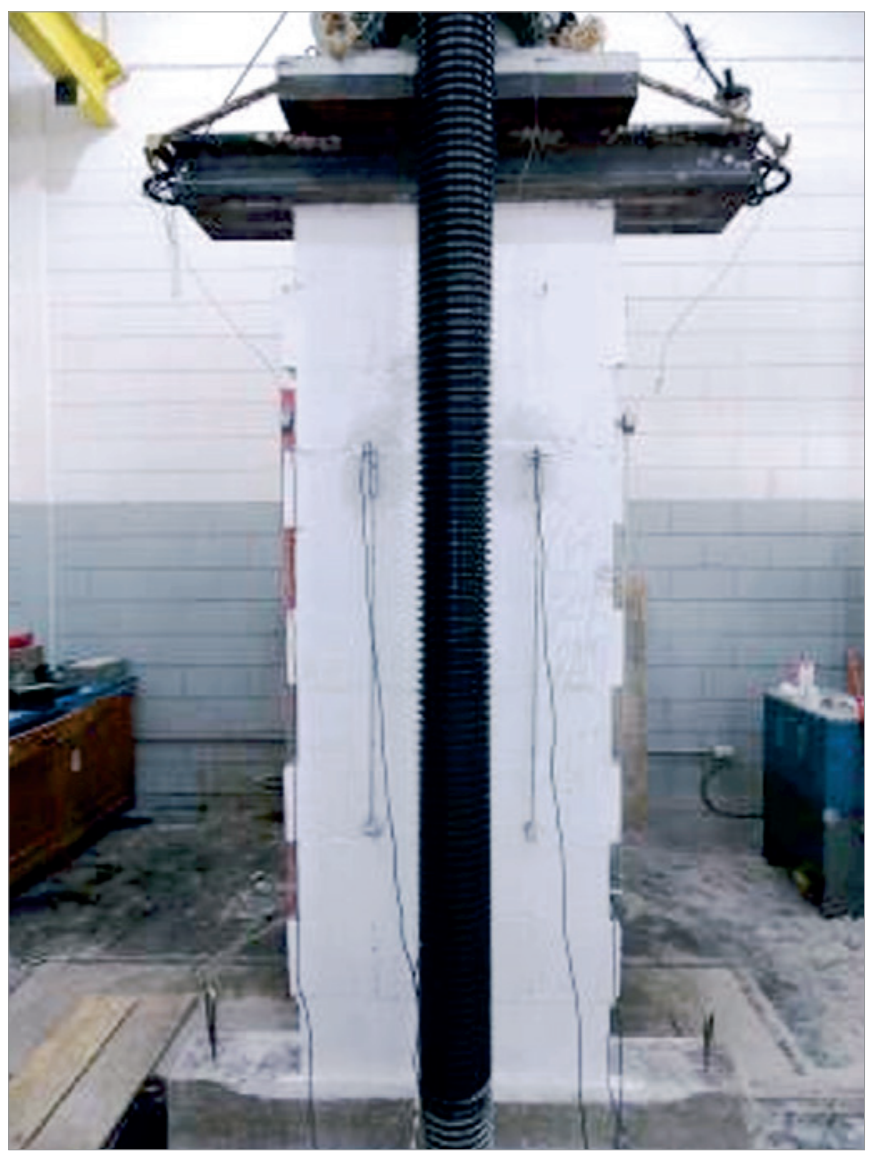


The Group 3 walls were tested using a self-reacting steel frame as shown in Figure 17. During the testing, the vertical displacements of both sides (Faces 1 and 2) of the walls were measured using 25-mm stroke displacement transducers (LVDTs) as shown in Figure 17. The precision of the LVDTs used was $0.000010 \mathrm{~mm}$. The vertical displacements of the sides of the wall were monitored continuously with wireless dial gauges, also shown in Figure 16.

To account for any accidental eccentricity of the loading during the test, measurements were taken on the front and on the back of the walls, as shown in Figure 18, and the mean value of the two measurements

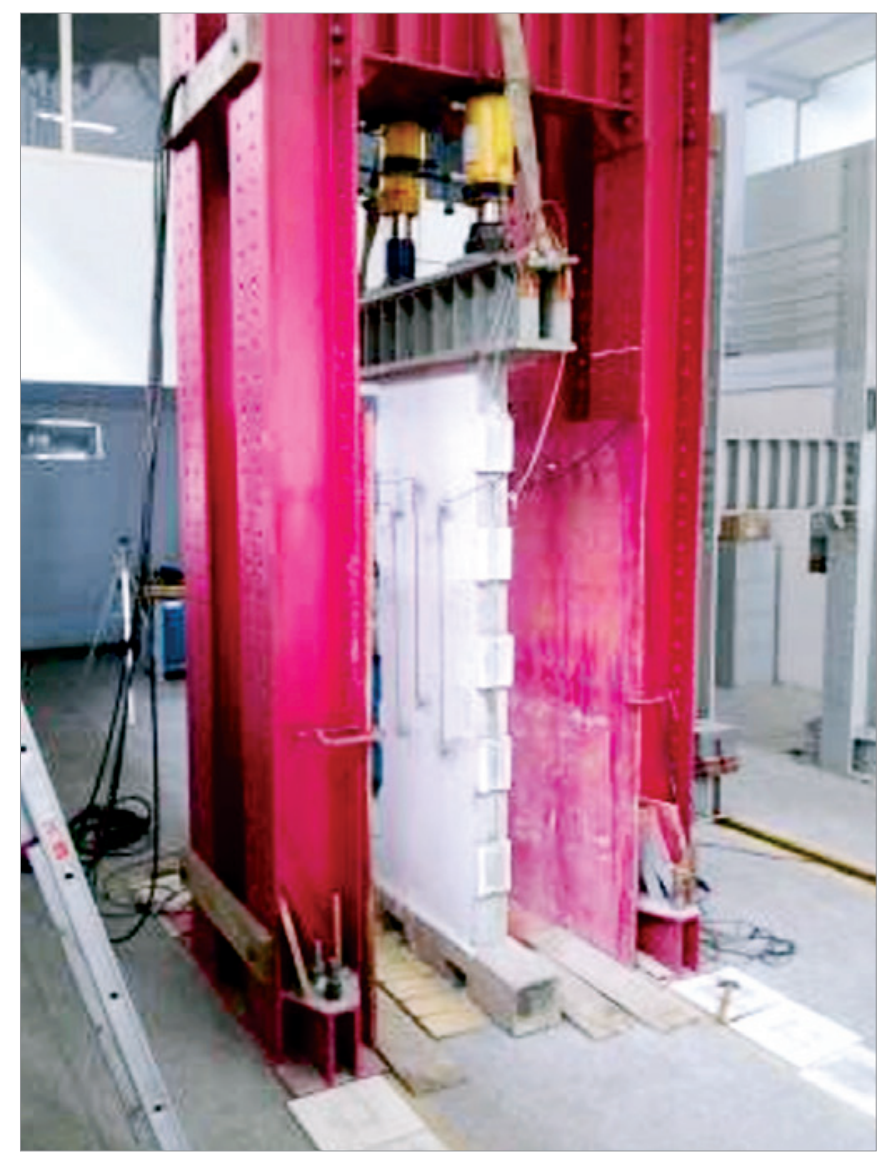

was used in the analysis. Before each test, the wall being tested was centered in test position and aligned vertically with the help of a laser level and a plumb line. The wall was then loaded and unloaded twice up to $5 \%$ of the maximum expected load to lock the wall in place and check the instrumentation readings. During each test, the vertical load was gradually applied with a rate of about $10 \mathrm{kN} / \mathrm{s}$ up to the failure.

\subsection{Experimental procedure}

Each test started by loading and unloading the wall twice up to

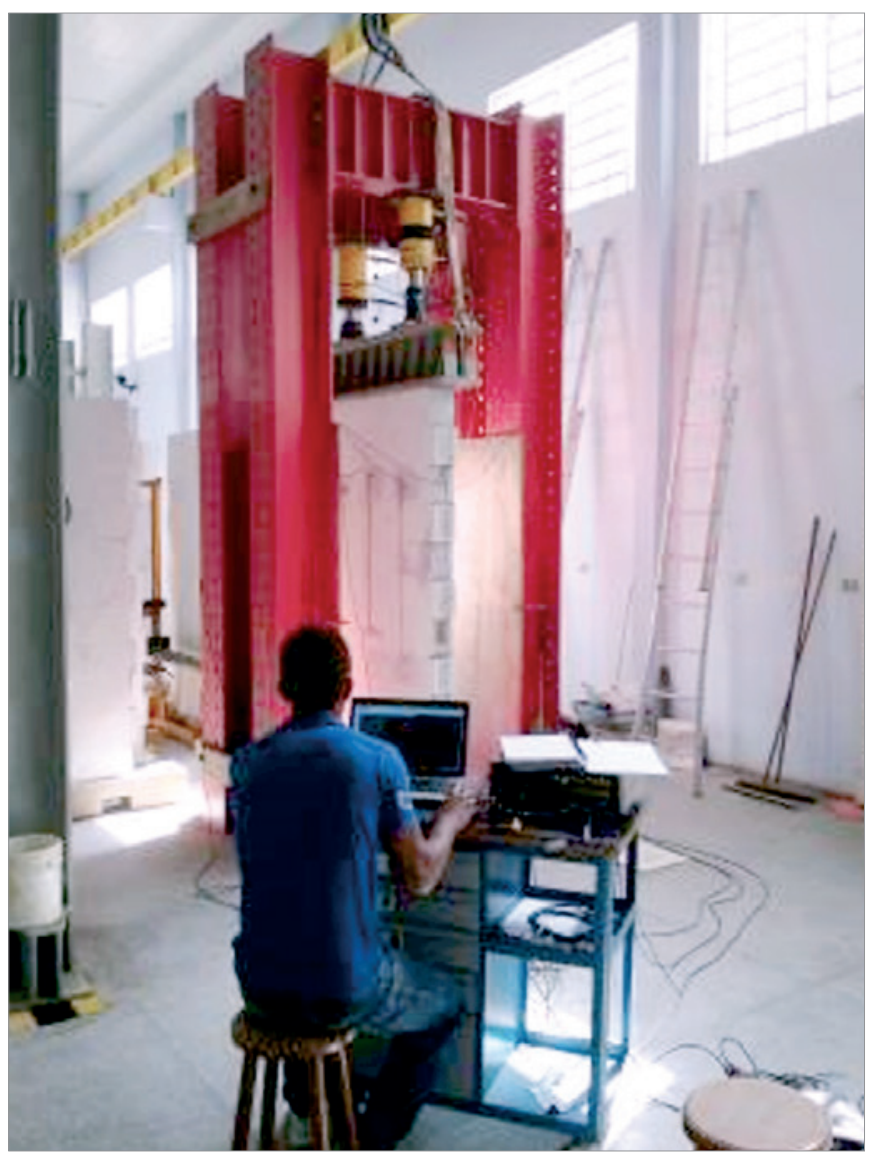

\section{Figure 17}

Walls testing. Group 3

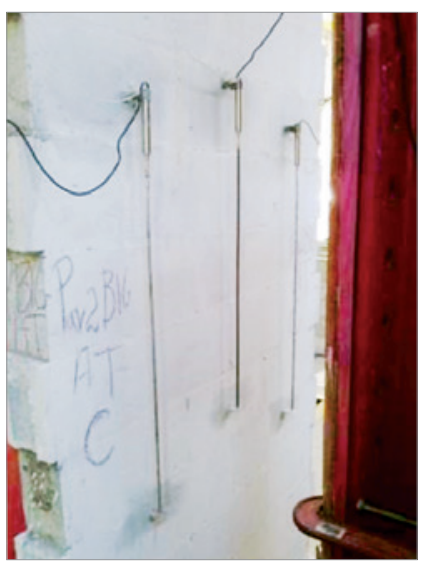

Group 3
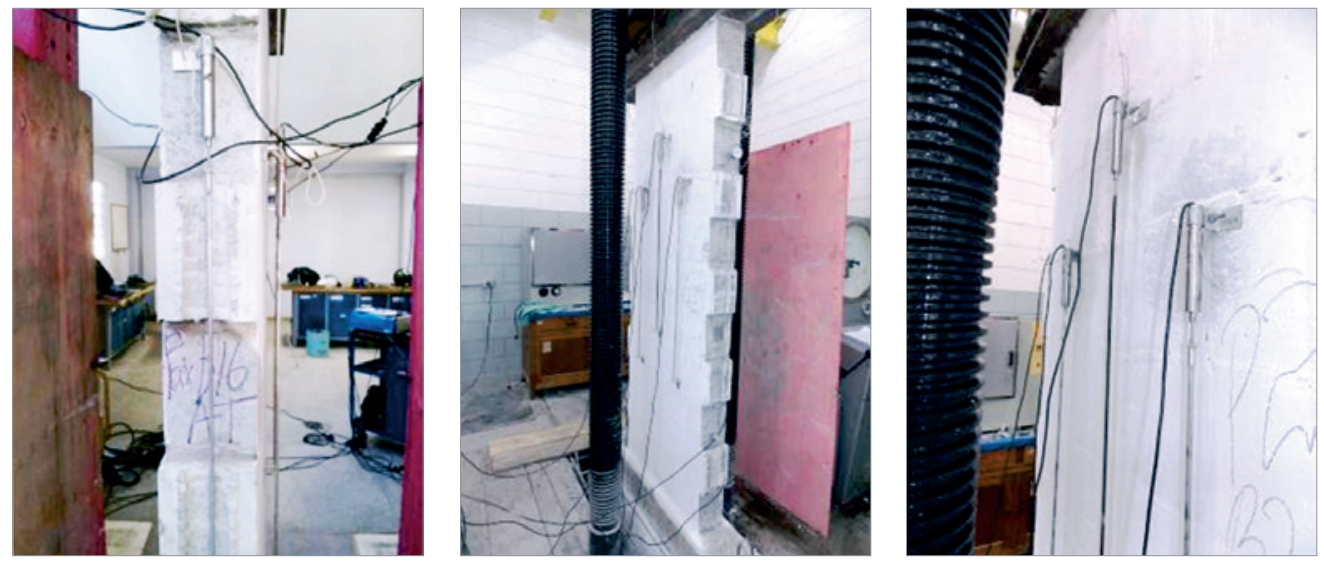

B Group 1 and 2

Figure 18

Wall instrumentation 
Table 7

Materials characterization methods

\begin{tabular}{|c|c|c|}
\hline Material & Method & Test \\
\hline Block & ABNT NBR 6136/2014 & Full absorption \\
\hline Block & ABNT NBR 12118/2013 & Compressive strength \\
\hline Block & ABNT NBR 121 18/2013 & Compressive strength \\
\hline Wall & ABNT NBR 8949/1985 & Compressive strength \\
\hline Wall mortar prism & ABNT NBR 15961-2/2011 & Compressive strength \\
\hline Grout & ABNT NBR 5738 & Specifications \\
\hline Grout & ABNT NBR 5739 & Flexural and compression strength \\
\hline Grout & ABNT NBR 7211 &
\end{tabular}

$50 \%$ of the maximum expected load. Then, the load was applied in increments equal to $10 \%$ of the expected failure load up to $50 \%$ of this value, waiting 5 minutes between each increment to allow obtaining and plotting of load vs displacement and stress vs strain curves. After this load, the axial load was gradually monotonically increased until failure of the wall. The load was read from the analog gauge at the compression machine used for testing groups 1 and 2 walls and directly from the data acquisition system for testing group 3 walls. Readings of the LVDTs were taken and recorded by a computer controlled data acquisition system. Data recording occur every second. A wall was considered to fail when vertical cracks appeared and the applied load started to decrease or when the wall exhibited large lateral deformation with a vertical load drop. The procedure adopted for each test is summarized in Table 7.

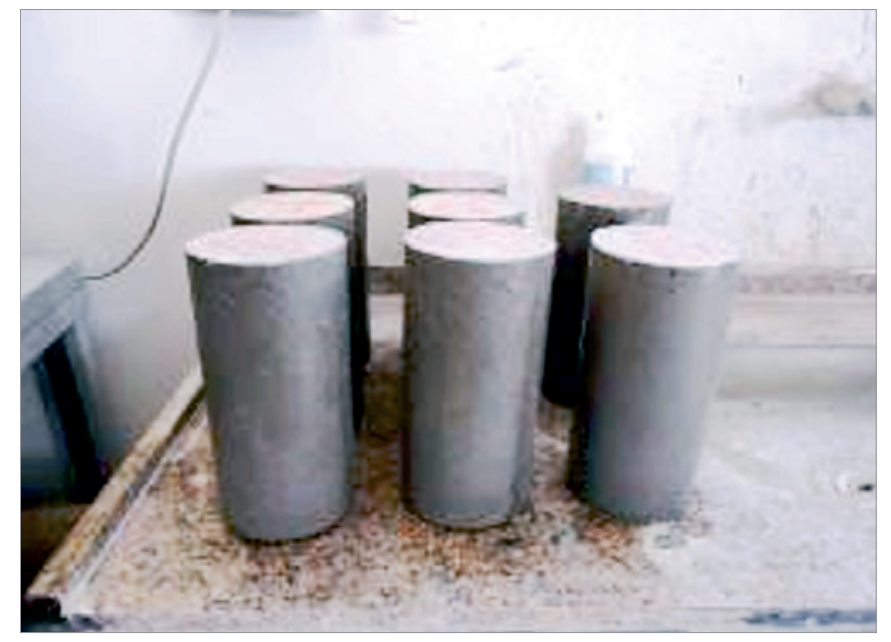

\section{Figure 19}

Grout specimens and testing

\section{Table 8}

Grout compressive strength

\begin{tabular}{|c|c|c|c|}
\hline Name & $\begin{array}{c}\text { Average compressive } \\
\text { strength }(\mathrm{MPa})\end{array}$ & $\begin{array}{c}\text { Standard deviation } \\
(\mathbf{M P a})\end{array}$ & $\begin{array}{c}\text { Coefficient of variation } \\
(\%)\end{array}$ \\
\hline$G_{1}$ & 31.3 & 2.35 & 7.5 \\
\hline$G_{2}$ & 34.9 & 3.92 & 11.2 \\
\hline$G_{3}$ & 42.4 & 2.68 & 6.3 \\
\hline
\end{tabular}

\section{Results and discussion}

A detailed description of the block, mortar, block, prism, and wall testing results are discussed below.

\subsection{Grout}

Figure 19 shows some ground grout specimens and one specimen after testing. The grout strength results according to their use in the walls and horizontal bond beams for Groups 1, 2 and 3 are presented in Table 8 .

\subsection{Mortar}

Figure 20 shows some mortar specimens and the testing assemblage. Table 9 presents the average compressive strength results for the mortar.

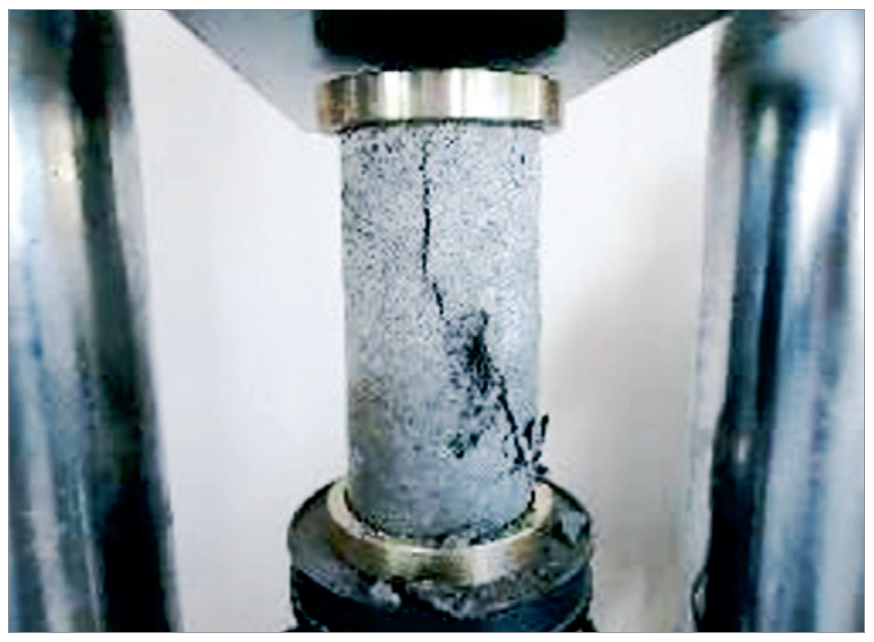



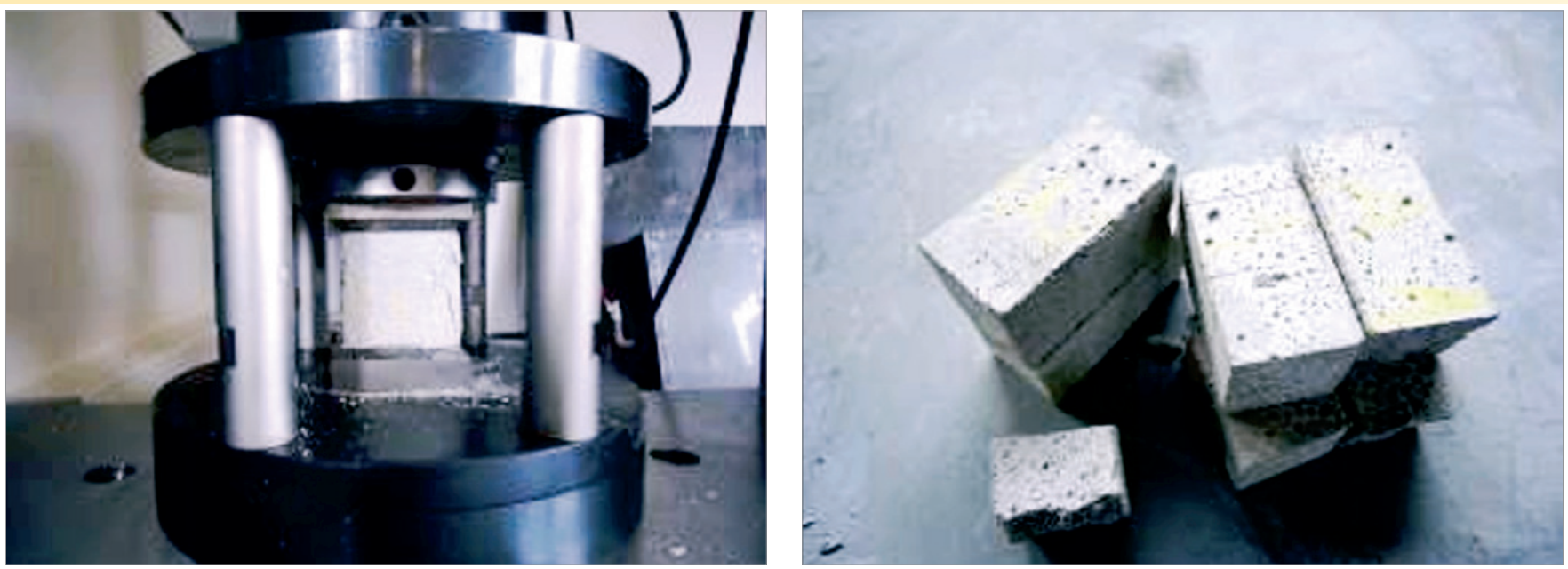

Figure 20

Mortar specimens and testing

Table 9

Mortar compressive strength

\begin{tabular}{|c|c|c|c|}
\hline Name & $\begin{array}{c}\text { Average compressive } \\
\text { strength (MPa) }\end{array}$ & $\begin{array}{c}\text { Standard deviation } \\
\text { (MPa) }\end{array}$ & $\begin{array}{c}\text { Coefficient of variation } \\
(\%)\end{array}$ \\
\hline $\mathrm{A}_{1}$ & 13.4 & 0.69 & 5.3 \\
\hline $\mathrm{A}_{2}$ & 21.8 & 0.65 & 3.0 \\
\hline $\mathrm{A}_{3}$ & 26.9 & 0.80 & 3.0 \\
\hline
\end{tabular}

\subsection{Block}

Figure 21 shows a block being tested and the block typical mode of failure. Table 10 presents the average compressive strength and the coefficients of variation results.

\subsection{Prism}

Figure 22 shows some hollow and grouted prisms, respectively after testing. Probably due to the high strength blocks, hollow prisms failure was not as the usual failure reported in the literature. The hollow prisms failed due to the development of vertical cracks along the loading direction followed by separation of the lateral walls of the blocks or by crushing of the mortar joint followed by separation of the blocks faceshell.

Results on the hollow and grouted prisms compressive strength are presented in Table 11 and Table 12, respectively. The tables also provide the standard deviations and coefficients of variation. The results presented in Table 13, Table 14, and Table 15 are $f_{\text {pa, }}$, $\Delta_{\mathrm{u}}, \Delta_{\mathrm{u} 50 \%}, \varepsilon_{\mathrm{u}}$, and $\varepsilon_{50 \%}$, representing the wall average compressive strength, the wall average maximum vertical shortening, the average vertical shortening at $50 \%$ of the maximum stress, the ultimate strain and the strain at $50 \%$ of the maximum stress, respectively. The strength results, the stress-strain curves for masonry in compression, the stress-strain relationship at the ultimate load, the effect of the mid-height grouted bond beam,
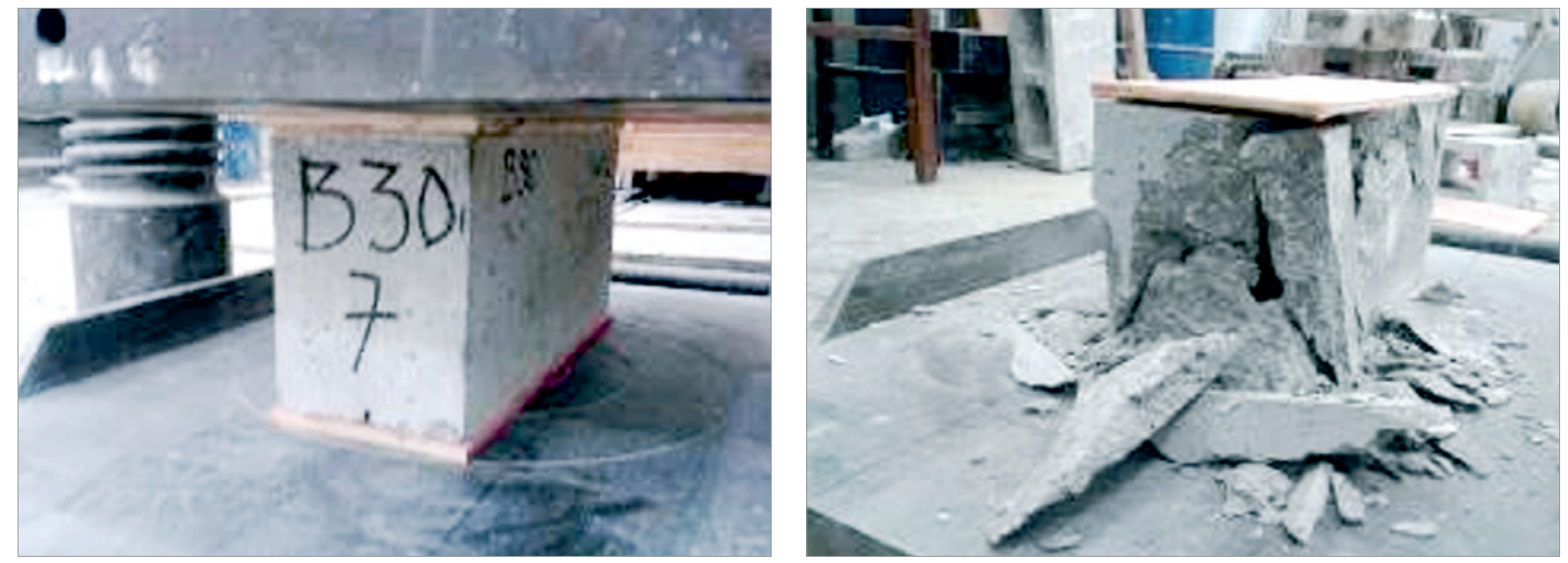

\section{Figure 21}

Block specimens and testing 

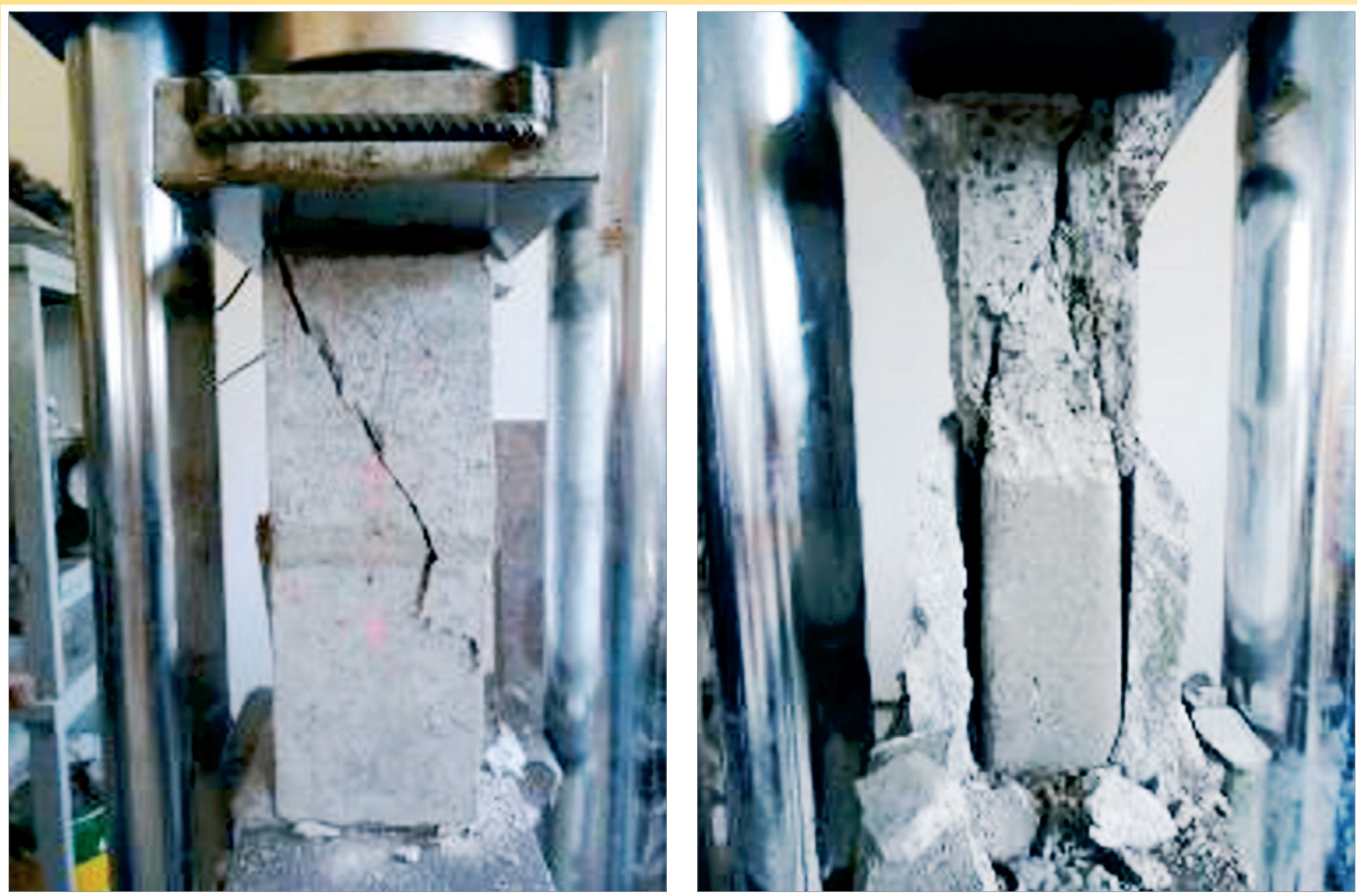

\section{Figure 22}

Hollow and grouted prism testing

Table 10

Block compressive strength

\begin{tabular}{|c|c|c|c|}
\hline Name & $\begin{array}{c}\text { Average compressive } \\
\text { strength (MPa) }\end{array}$ & $\begin{array}{c}\text { Standard deviation } \\
(\mathrm{MPa})\end{array}$ & $\begin{array}{c}\text { Coefficient of variation } \\
(\%)\end{array}$ \\
\hline $\mathrm{B}_{1}$ & 18.7 & 1.1 & 5.9 \\
\hline $\mathrm{B}_{2}$ & 27.3 & 3.0 & 11.0 \\
\hline $\mathrm{B}_{3}$ & 34.5 & 0.4 & 1.0 \\
\hline
\end{tabular}

Table 11

Hollow prism compressive strength

\begin{tabular}{|c|c|c|c|}
\hline \multirow{2}{*}{ Name } & \multicolumn{3}{|c|}{ Two-block hollow prism assemblage } \\
\cline { 2 - 4 } & $\mathbf{B}_{\mathbf{1}}-\mathbf{A}_{\mathbf{1}}$ & $\mathbf{B}_{\mathbf{2}}-\mathbf{A}_{\mathbf{2}}$ & $\mathbf{B}_{\mathbf{3}}-\mathbf{A}_{\mathbf{3}}$ \\
\hline Average compressive strength (MPa) & 10.0 & 13.3 & 16.9 \\
\hline Standard deviation (MPa) & 0.90 & 1.26 & 1.45 \\
\hline Coefficient of variation (\%) & 8.96 & 9.46 & 8.6 \\
\hline
\end{tabular}

\section{Table 12}

Grouted prism compressive strength

\begin{tabular}{|c|c|c|c|}
\hline \multirow{2}{*}{ Result } & \multicolumn{3}{|c|}{ Two-block hollow prism assemblage } \\
\cline { 2 - 4 } & $\mathbf{B}_{\mathbf{1}}-\mathbf{A}_{\mathbf{1}}-\mathbf{G}_{\mathbf{1}}$ & $\mathbf{B}_{\mathbf{2}}-\mathbf{A}_{\mathbf{2}}-\mathbf{G}_{\mathbf{2}}$ & $\mathbf{B}_{\mathbf{3}}-\mathbf{A}_{\mathbf{3}}-\mathbf{G}_{\mathbf{3}}$ \\
\hline Average compressive strength (MPa) & 22.3 & 29.0 & 32.2 \\
\hline Standard deviation (MPa) & 1.1 & 2.8 & 1.2 \\
\hline Coefficient of variation (\%) & 4.75 & 9.6 & 3.7 \\
\hline
\end{tabular}


the mortar laying type, the grouting effect on the wall compression capacity, and the failure mode are discussed in the subsequent sections.

\subsection{Group 1-Walls with 30-MPa high-strength concrete blocks $\left(B_{3}\right)$}

The results of the tests for Group 1 walls are presented in table 13
For the hollow walls with full bed mortar joints, the average failure stress was equal to $11.43 \mathrm{MPa}$. For hollow walls with face-shell mortar joints, the average failure stress was equal to $11.82 \mathrm{MPa}$. This result is unexpected, the walls with full mortar bed joints were expected to have greater strength than those constructed with face-shell mortar joints. The difference in the average wall strength is only $3.3 \%$. Applying a t-test on the results, a p-value equal to $22.5 \%$ was determined, indicating that, statistically, the averages

Table 13

Walls with block $B_{3}$ results

\begin{tabular}{|c|c|c|c|}
\hline Wall name & $f_{p a}(M P a)$ & $\Delta_{\mathrm{u} 50 \%}(\mathrm{~mm})$ & $\varepsilon_{\mathrm{u} 50 \%}(\mathrm{~mm} / \mathrm{mm})$ \\
\hline \multicolumn{4}{|c|}{ Par-B3-O-AT } \\
\hline Average & 11.4 & 0.49 & 0.0006 \\
\hline Coefficient of variation & 4.45 & 28.90 & 27.98 \\
\hline \multicolumn{4}{|c|}{ Par-B3-O-AP } \\
\hline Average & 11.8 & 0.48 & 0.0006 \\
\hline Coefficient of variation & 4.89 & 17.69 & 19.16 \\
\hline \multicolumn{4}{|c|}{ Par-B3-O-AT-CT } \\
\hline Average & 11.1 & 0.46 & 0.0005 \\
\hline Coefficient of variation & 3.88 & 7.93 & 5.09 \\
\hline \multicolumn{4}{|c|}{ Par-B3-G-AT-CT } \\
\hline Average & 19.0 & 0.49 & 0.0006 \\
\hline Coefficient of variation & 14.03 & 24.44 & 19.58 \\
\hline
\end{tabular}

\section{Table 14}

Walls with block $B_{2}$ results

\begin{tabular}{|c|c|c|c|}
\hline Wall name & $\mathbf{f}_{\mathrm{pa}}(\mathrm{MPa})$ & $\Delta_{\mathrm{u}}(\mathrm{mm} / \mathrm{mm})$ & $\varepsilon_{\mathrm{u}}(\mathrm{mm} / \mathrm{mm})$ \\
\hline \multicolumn{5}{|c|}{ Par-B2-O-AP } \\
\hline Average & 10.7 & 0.78 & 0.0008 \\
\hline Coefficient of variation & 0.9 & 15.68 & 19.60 \\
\hline \multicolumn{5}{|c|}{ Par-B2-O-AT-CT } \\
\hline Average & 11.8 & 0.97 & 0.0012 \\
\hline Coefficient of variation & 3.3 & 22.22 & 19.64 \\
\hline \multicolumn{7}{|c|}{ Par-B2-G-AT-CT } \\
\hline Average & 19.8 & 1.20 & 0.0013 \\
\hline Coefficient of variation & 10.7 & 18.65 & 16.31 \\
\hline
\end{tabular}

\section{Table 15}

Walls with block $B_{1}$ results

\begin{tabular}{|c|c|c|c|}
\hline Wall name & $f_{\mathrm{pa}}(\mathrm{MPa})$ & $\Delta_{\mathrm{u}}(\mathrm{mm} / \mathrm{mm})$ & $\varepsilon_{\mathrm{u}}(\mathrm{mm} / \mathrm{mm})$ \\
\hline \multicolumn{5}{|c|}{ Par-B1-O-AT-CT } \\
\hline Average & 7.8 & 0.72 & 0.0008 \\
\hline Coefficient of variation & 6.19 & 23.45 & 19.60 \\
\hline \multicolumn{7}{|c|}{ Par-B1-O-AP } \\
\hline Average & 7.8 & 0.98 & 0.0011 \\
\hline Coefficient of variation & 8.35 & 21.75 & 23.47 \\
\hline \multicolumn{7}{|c|}{ Par-B1-G-AT-CT } \\
\hline Average & 11.5 & 1.06 & 0.0012 \\
\hline Coefficient of variation & 20.22 & 24.88 & 27.39 \\
\hline
\end{tabular}


are equal to a significance level of $95 \%$. The average shortenings, $\Delta_{\text {u50\% }}$, of all walls of Group 1 varies from 0.46 to $0.49 \mathrm{~mm}$. Clearly, the shortening of the walls is indifferent to the variables considered. The average strains, $\Delta_{\mathrm{u} 50 \%}$, are also similar, with values of $0.0006,0.0006,0.0005$, and 0.0006 , respectively for the full mortar bed joint hollow walls, face-shell mortar joint hollow walls, full mortar bed joint hollow walls with a mid-height bond beam, and grouted walls with a mid-height bond beam.

The Brazilian concrete block structural masonry standard, NBR 15961-2 [23], specify that the compressive strength of walls constructed with face-shell mortar joints should be considered as $20 \%$ lower than that of a wall with full bed mortar joint. The results presented here do not corroborate the reduction indicated by the standard. The geometry of the blocks may explain the similar results obtained herein. Due to the running bond pattern used, the position and thickness of the block web do not align vertically with that of the block web placed on its top. Therefore, laying blocks with full bed mortar joints may have been inefficient because there is no vertical alignment of the webs.

The average compressive strengths were 19.0 and $11.1 \mathrm{MPa}$ for the grouted and ungrouted walls (both with a mid-height bond beam), respectively, representing an increase in strength for the grouted walls of approximately $66 \%$.

\subsection{Group 2-Walls with high-strength concrete blocks of $24 \mathrm{MPa}\left(\mathrm{B}_{2}\right)$}

Group 2 test results are shown in table 14

For hollow walls with full bed mortar joints and with a mid-height bond beam, the average strength was $11.77 \mathrm{MPa}$ while the hollow walls with face-shell mortar joints without a mid-height bond beam, the average strength was $10.69 \mathrm{MPa}$. The capacity of the hollow walls with full bed mortar joints with a mid-height beam is approximately $10 \%$ higher than that of the walls with face-shell mortar

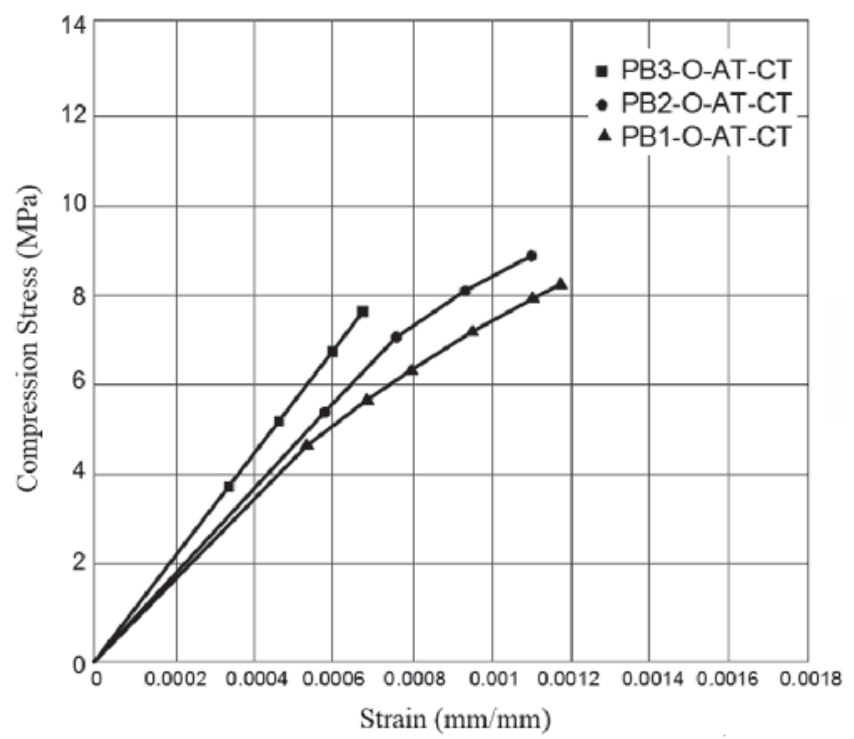

Figure 23

Walls PB-O-AT-CT stress vs strain results joints without a mid-height bond beam. The t-test indicates a $\mathrm{p}$ value of $2.7 \%$. indicating that there is difference between the average strengths. The existence of the mid-height bond beam may have contributed to better stress distribution the wall critical region and contributed to the strength increase for the full bed mortar joint walls. However, the walls in Group 3 did not experienced the same kind of results, which invalidates this assumption. The wall shortenings at the failure loads, $\Delta_{u}$, were, respectively 0.970 .78 and $1.20 \mathrm{~mm}$ for the hollow walls with full bed mortar joints with a mid-height bond beam, for the hollow walls with face-shell mortar joints, and for the grouted walls with a mid-height bond beam. There is therefore a variability in the walls shortening. The average strains at ultimate loads, $\varepsilon_{\mathrm{u}}$, were $0.0012,0.0013$, and $0.0008 \mathrm{~mm} /$ $\mathrm{mm}$, respectively.

When comparing the hollow full bed mortar joint walls with the grouted wall, both with a mid-height bond beam, the average strength of $11.77 \mathrm{MPa}$ obtained for the hollow walls case is increased to $19.79 \mathrm{MPa}$ for the fully grouted walls. The average compressive capacity of the grouted wall is approximately $68 \%$ higher than that of the hollow walls.

\subsection{Group 3-Walls with high-strength concrete blocks of $16 \mathrm{MPa}\left(B_{1}\right)$}

Group 2 test results are presented in table 15.

The average compressive strength was $7.8 \mathrm{MPa}$ for both hollow face-shell mortar joint walls without a mid-height bond beam and the hollow full -bed mortar joint walls with a mid-height bond beam. Therefore, there was no significant difference between the type of bedding and the presence or not of a mid-height bond beam on the wall strength.

The wall vertical shortening, $\Delta_{\mathrm{u}}$, was respectively $1.06,0.98$, and 0.72 for hollow walls with full bed mortar joints and with a midheight bond beam, for hollow walls with face-shell mortar joints, and for the grouted walls with a mid-height bond beam. As happened with the walls of the Group 2, some difference in the vertical shortening of walls is observed. The average ultimate shortening, $\varepsilon_{\mathrm{u}}$, were $0.0008,0.0011$, and 0.0012 , respectively.

When comparing the hollow full bed mortar joint walls with the grouted wall, both with a mid-height bond beam, the average strength of $7.78 \mathrm{MPa}$ obtained for the hollow walls case is increased $11.53 \mathrm{MPa}$ for fully grouted walls. The average compressive capacity of the grouted wall is approximately $48 \%$ higher than that of the hollow walls.

\subsection{Stress-strain relationship}

To assess the effect of the mid-height bond beam, of the grouting or non-grouting, and of full or face-shell bed mortar joints on the stress-strain relationship of high-strength masonry in compression, the stress-strain curves were plotted. The average ultimate strain for the walls of groups 2 and 3 were calculated using the vertical displacements within a calibrated measurement length on the walls faces. The ultimate strain for walls of groups 2 and 3 and the $50 \%$ of ultimate load strain for walls the Group 1 are presented in Table 13, Table 14, and Table 15, respectively. The average ultimate strain for walls of groups 2 and 3 ranged from 0.001 to 


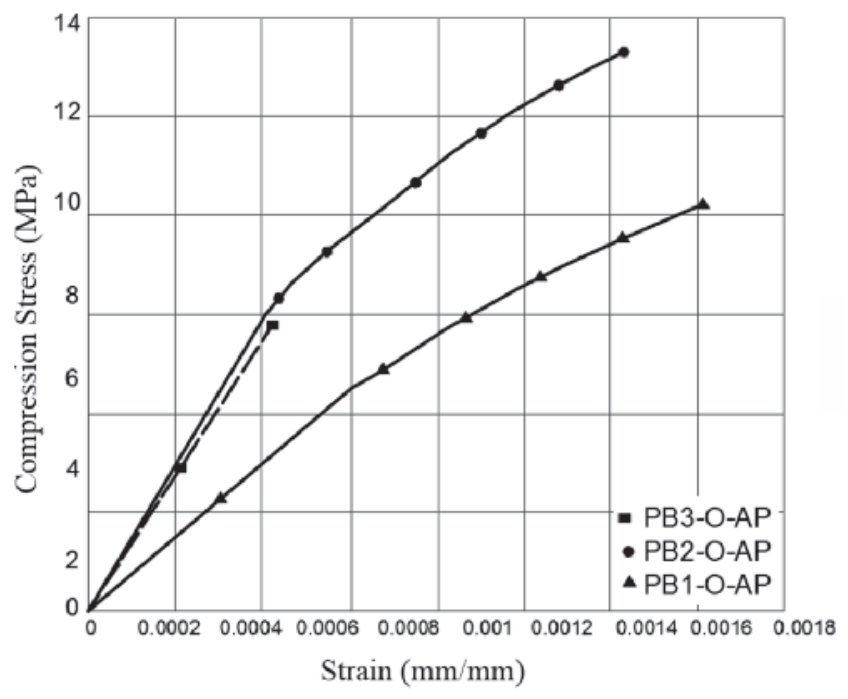

Figure 24

Walls PB-O-AP stress vs strain results

0.0015 . For the walls of Group 1, the strains were measured up to $50 \%$ of the failure load and ranged from 0.0005 to 0.0006 .

The stress-strain curves for the walls with the same characteristics of each group are presented in Figure 23, Figure 24, and Figure 25 . The compression stresses were calculated considering the wall gross area. For the walls PB3-O-AT-CT, PB3-O-AP, and PB3-GAT-CT, the curves are up to $50 \%$ of failure load only while for the remaining walls the curves were obtained up to failure. The results presented in Figure 23, Figure 24, and Figure 25 show a brittle behavior for all walls tested.

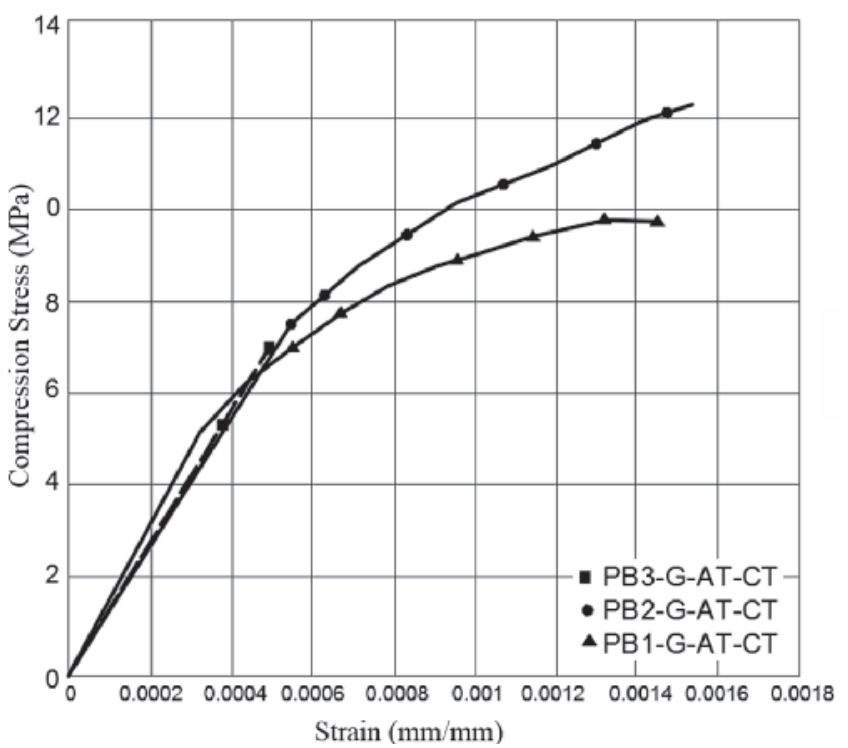

Figure 25

Walls PB- G-AT-CT stress vs strain results

For the full bed mortar joint hollow walls with a mid-height bond beam, the stress-strain curve shown in Figure 23 remained approximately linear up to $75 \%$ of failure load. For the face-shell bed mortar joint hollow walls without a mid-height bond beam, the stress-strain curve shown in Figure 24 remained approximately linear up to $70 \%$ of failure load. In the case of the grouted walls with and without a mid-height bond beam, the stress-strain curve shown in Figure 25 remained approximately linear up to $60 \%$ of

Table 16

Wall elastic modulus results

\begin{tabular}{|c|c|c|c|}
\hline Wall name & Grupo 1 Par - B $_{3}$ & Group 2 Par $-B_{2}$ & Group 3 Par - B \\
\hline \multicolumn{4}{|c|}{ Par-O-AT } \\
\hline E (average) (MPa) & 20631 & - & - \\
\hline$E_{a}\left(800 f_{p}\right)(M P a)$ & 13520 & - & - \\
\hline Coefficient of variation & $26.05 \%$ & - & - \\
\hline \multicolumn{4}{|c|}{ Par-O-AP } \\
\hline E (average) (MPa) & 20283 & 19658 & 14327 \\
\hline EA $\left(800 f_{p}\right)(M P a)$ & 13520 & 10640 & 8000 \\
\hline Coefficient of variation & $8.31 \%$ & $8.07 \%$ & $4.76 \%$ \\
\hline \multicolumn{4}{|c|}{ Par-O-AT-CT } \\
\hline E (average) (MPa) & 23438 & 20473 & 15781 \\
\hline$E_{a}\left(800 f_{p}\right)(M P a)$ & 13520 & 10640 & 8000 \\
\hline Coefficient of variation & $13.96 \%$ & $6.71 \%$ & $4.68 \%$ \\
\hline \multicolumn{4}{|c|}{ Par-G-AT-CT } \\
\hline E (average) (MPa) & 24219 & 23927 & 15394 \\
\hline$E_{\alpha}\left(800 f_{f}\right)(M P a)$ & 25760 & 23200 & 17840 \\
\hline Coefficient of variation & $17.14 \%$ & $34.17 \%$ & $-12.97 \%$ \\
\hline
\end{tabular}




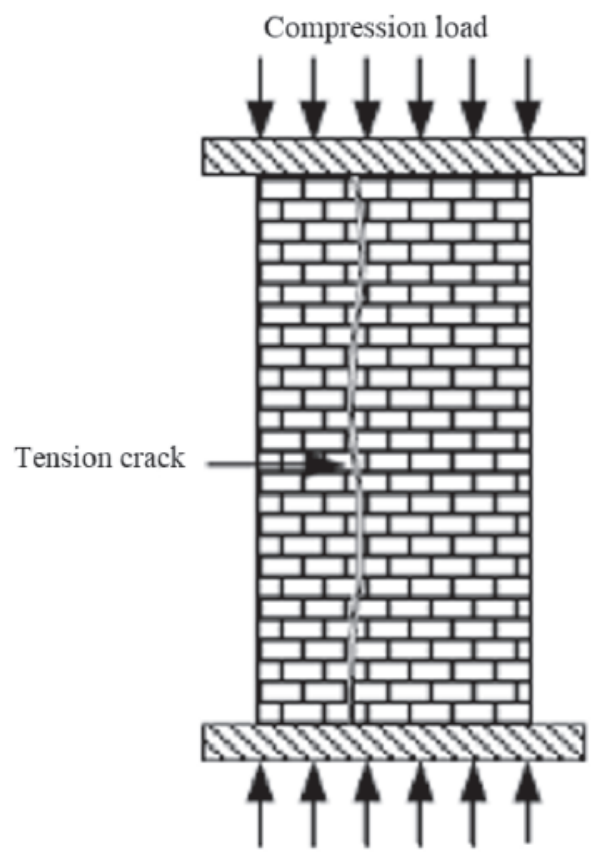

Compression load

\section{Figure 26}

Wall typical failure mode (Hendry et al 2004)
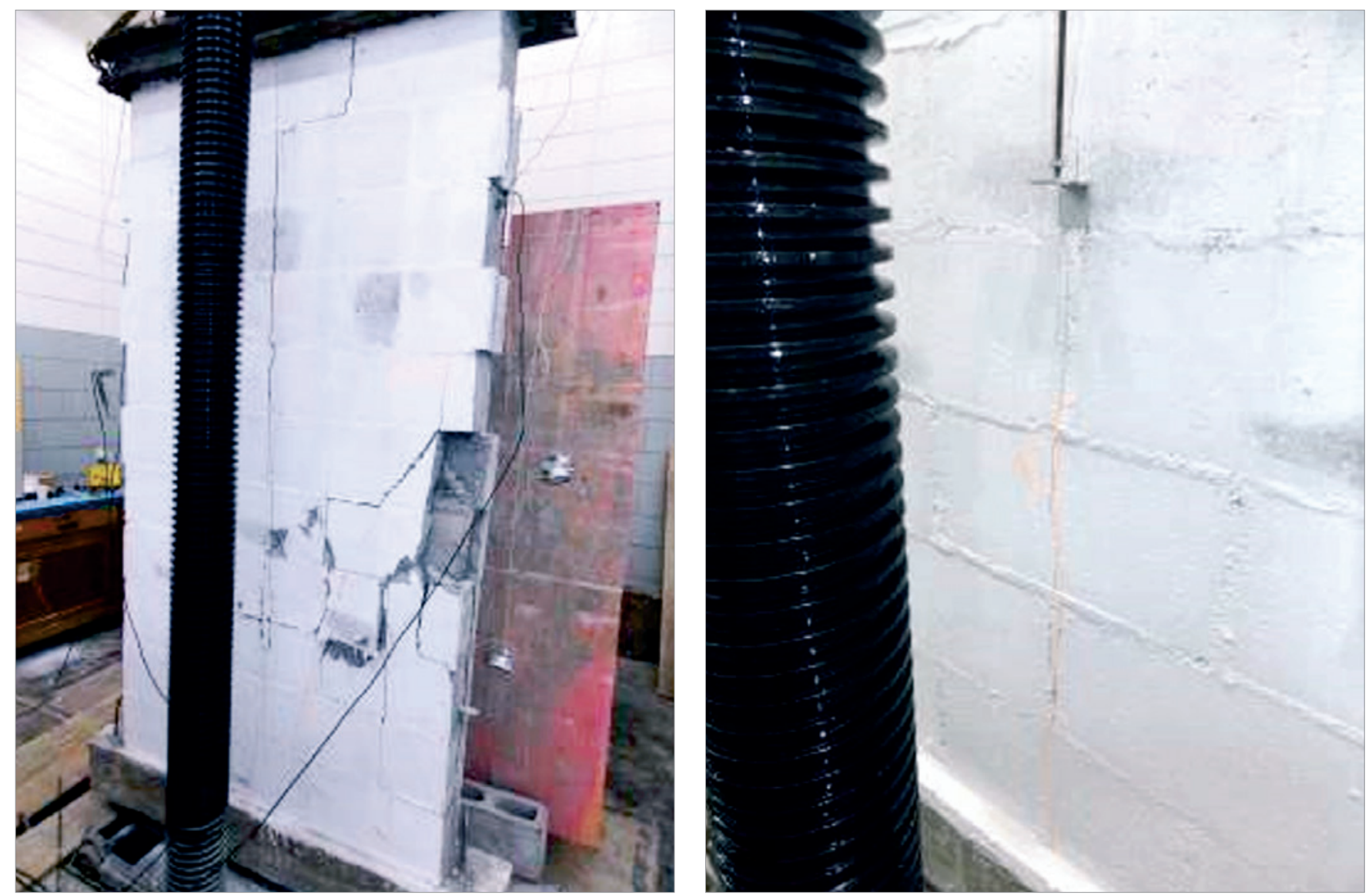

\section{Figure 27}

Wall with mid-height bond beam failure 
failure load. Results indicate that each variable has a small effect on the strain-strain curve shape.

A comparison of stress-strain curve between the hollow or grouted walls indicates that, overall, the shape of the stress-strain curve is similar, with that of the grouted wall being slightly more nonlinear.

\subsection{Modulus of elasticity of masonry}

The modulus of elasticity was considering as the secant line of the strain-strain curve between 5 and $30 \%$ of the failure stress. The modulus of elasticity can also be calculated as a function of the compressive strength of masonry, and these estimates are usually presented in standard codes. The ABNT NBR 15961-1[4] specifies that the modulus of elasticity of concrete block masonry can be estimated as $800 \mathrm{f}_{\mathrm{pk}}$.

Table 16 shows the average results of the modulus of elasticity obtained for the walls using the linear part of the stress-strain curves. On average, the results of the secant modulus of Group 1 walls ranged from $20.2 \mathrm{GPa}$ for the hollow walls to $24.2 \mathrm{GPa}$ for the grouted walls. The results of the secant modulus of elasticity of Group 2 walls ranged from $19.6 \mathrm{GPa}$ for the hollow walls to 23.9 $\mathrm{GPa}$ for the grouted walls. Group 3 walls results ranged from 14.3 GPa for the hollow walls to $15.4 \mathrm{GPa}$ for the grouted walls.

Considering the standard ABNT NBR 15961-2 [23], which speci- fies the modulus of elasticity of masonry equal to $800 \mathrm{f}_{\mathrm{pk}}$, limited to $16 \mathrm{GPa}$, the calculated values are far superior for all hollow walls results, being considerably larger than $16 \mathrm{GPa}$, between $50 \%$ to almost $100 \%$ higher. In the case for the grouted walls, the calculated values are close to those estimated with $E=800 f_{p}$, with differences between $-14 \%$ and $+6 \%$; that is, between $688 f_{p}$ the $848 f_{p}$.

\subsection{Failure mode}

Failure mode of masonry in compression is usually caused by a tension crack that propagates through the blocks and mortar in the direction of the applied force, as shown in Figure 26. This crack is caused by secondary tension stress resulting from the deformation of block and confined mortar in the masonry joints (Hendry et al. [2]). The tensile stresses that induce the cracks are developed in the mortar-block interfaces due to restricted deformation of the mortar. In most cases, the masonry strength is considerably smaller than the block strength, which, however, is considerably higher than that of the mortar. The apparent increase in the mortar strength is due to the biaxial or tri-axial stress state imposed to the mortar when it is loaded in conjunction with the blocks.

The observed failure mode in typical in compression and was started by vertical cracks in the longitudinal and transverse faces of the walls as shown in Figure 27 and Figure 31 . The verticals cracks
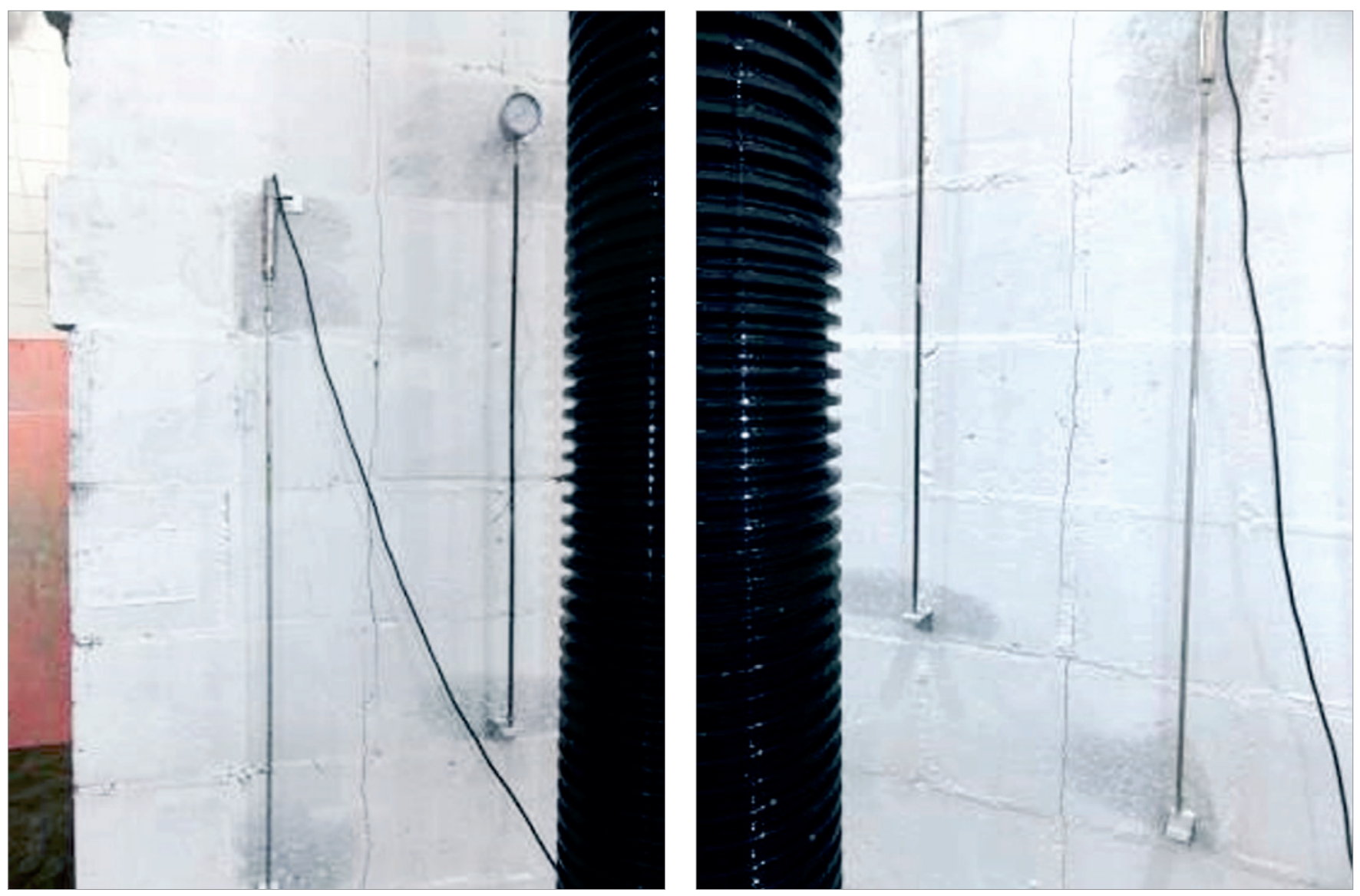

Figure 28

Hollow wall failure 
began because of tensile cracking, with some evidence of crushing of mortar, as shown in Figure 29. In some cases, as shown in Figure 30 , the development of cracks happened right in the middle of the walls and sometimes a little away from the center.

For the grouted walls with a mid-height bond beam, the failure mode was characterized by vertical separation cracks of the blocks webs, as shown in the Figure 31. For Groups 1 and 2 walls, the first crack was observed at about $60 \%$ of the ultimate load. For Group 3 walls, cracking started at approximately $75 \%$ of the failure load. Grouted walls with a mid-height bond beam presented an atypical type of rupture when compared to the wall without the mid-bond beam, as shown in Figure 31. The failure load, However, was similar to that of walls without the mid height bond beam.

\section{$3.11 \mathrm{Wall} / \mathrm{prism} / \mathrm{block}$ strength ratio}

The Brazilian standard allows the strength of the wall, $\mathrm{f}_{\mathrm{k}}$, to be equal to $70 \%$ of the strength of the prism, $\mathrm{f}_{\mathrm{pk}}$. Full-scale walls typically have lower strength than that of the prism and the prism strength is inferior to that of the block strength due to the slenderness effect and possibility of non-uniform load distribution. Fortes [21] noted in his research with several block strengths a decrease in the prism strength as the block strength increases and calculated values of efficiency ranging from 0.8 to 0.5 for 6.0 to $34.0 \mathrm{MPa}$ blocks. Table 17 summarizes the compressive strength of blocks, mortar, prisms, and grouted and hollow walls. The strength efficiencies, here defined as the ratio between the compressive strength of the walls to the compressive strength of the prisms, are also presented.

For Group 1 walls, the ratio of the compressive strength of the hol- low walls with full bed mortar joints to the compressive strength of hollow prisms (also with full bed mortar joints) is 0.7 . When the mid height bond beam is included in the wall, the compressive strength ratio remains equal to 0.7 . The ratio between the average compressive strength of grouted walls with a mid-height bond beam to the grouted prism strength, however, is equal to 0.6.

For the walls of Group 2, the ratio of compressive strength of hollow full bed mortar joint walls with a mid-height bond beam and the hollow prisms is 0.9 while that for the hollow walls with face-shell mortar joints and without a mid-height bond beam is 0.8 . For the grouted walls with a mid-height bond beam, the ratio to the grouted prism is 0.7 .

For the walls of the 3 Group, the ratio of the compressive strength of face-shell mortar joint hollow walls to the compressive strength of hollow prisms is 0.8 . The same ratio value was obtained for the full bed mortar joint hollow walls built with the mid height bond beam. In the case of the grouted wall built with the mid height bond beam, the strength ratio to the grouted prism is only 0.5 .

Therefore, the results indicate that it is safe to use the conventional wall to prism strength ratio equal to 0.7 for hollow walls even for high-strength blocks. In the case of grouted walls, a wall to prism strength ratio equal to 0.5 is recommended.

An Anova on the results for the walls built with the same $B_{3}$ block type was conducted. The test aimed to verify if there is significant difference in the compressive strength when considering:

- Hollow walls built with concrete blocks with full bed mortar joints and with a mid-height bond beam: PB3-O-AT-CT;

- Hollow walls built with concrete blocks with full bed mortar joints and without a mid-height bond beam: PB3-O-AT;
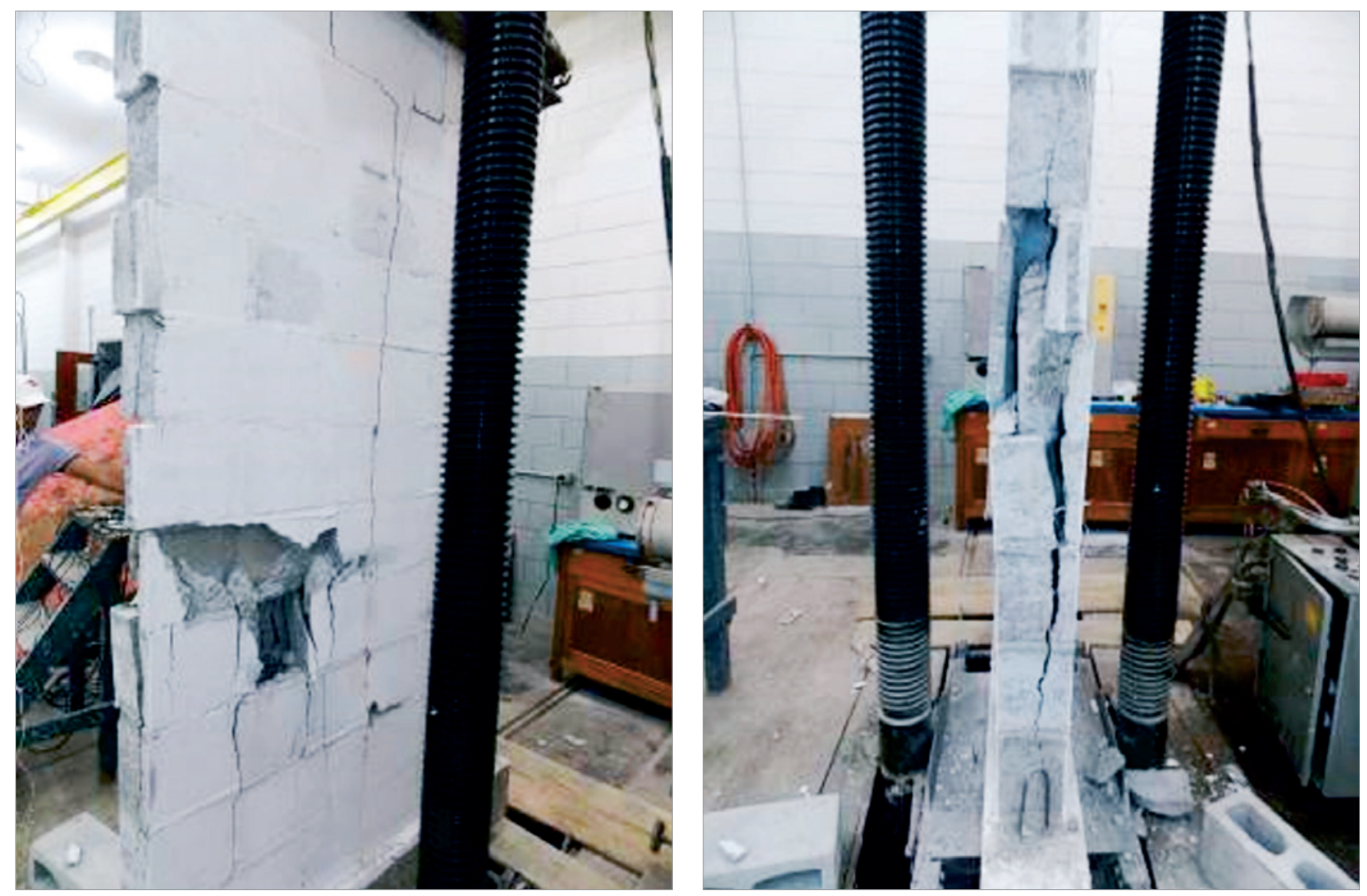

Figure 29

Wall vertical cracking and failure 

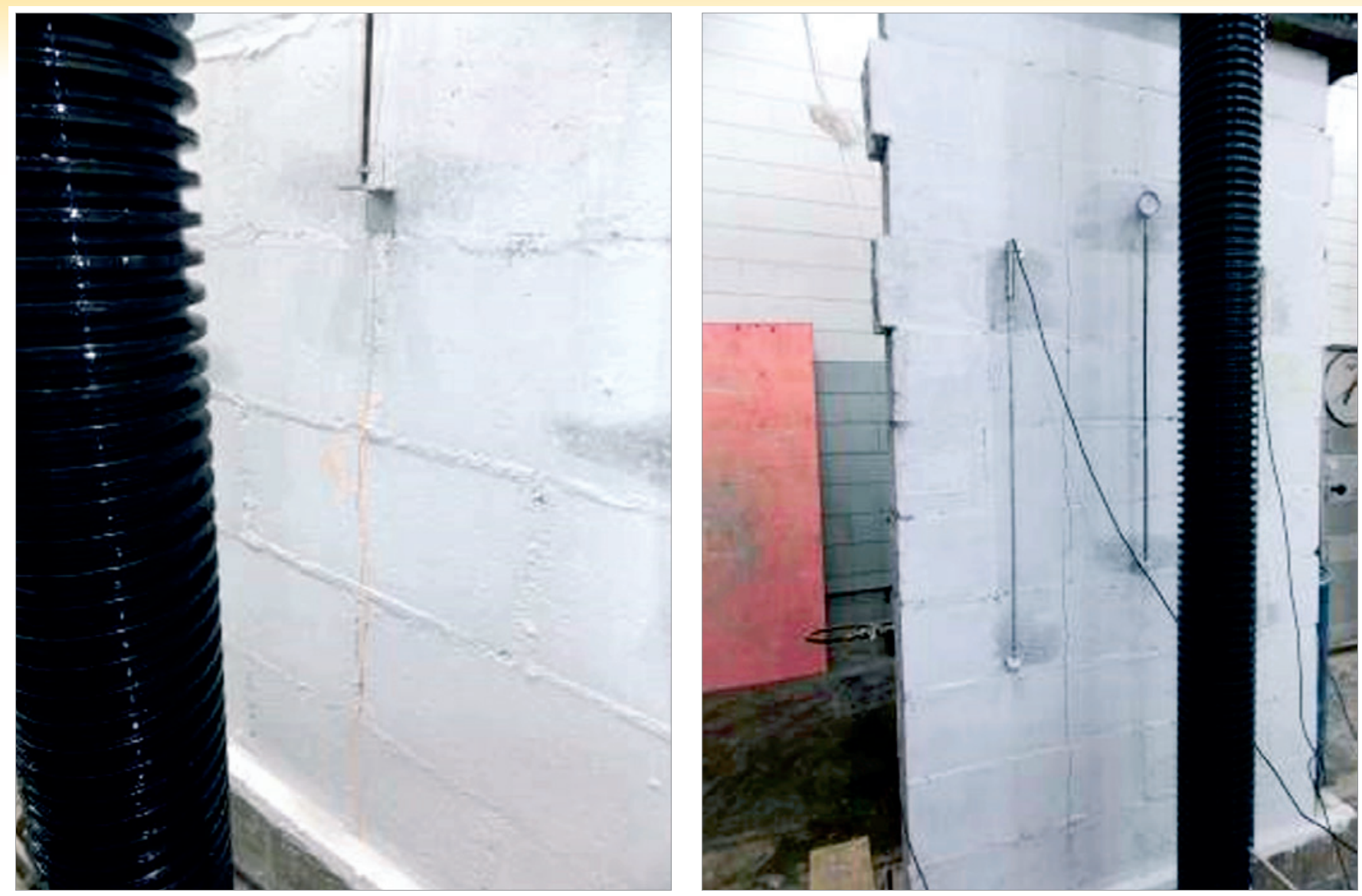

Figure 30

Wall vertical cracking and failure Wall vertical cracking Group 1 e 2

- Hollow walls built with concrete blocks with face-shell mortar joints and without a mid-height bond beam: PB3-O-AP.

Three specimens were tested into axial compressive loading for each type of test. Based on the results of the ANOVA test, varying the type of mortar bedding and the presence of a mid-height bond beam, it was determined that $F_{0}=<2.34$ and $F_{\alpha \text {. u1. u2 }}=5.14$. So, there is no difference in the average result among PB3-O-AT-CT, PB3-O-AT, and PB3-O-AP.

For the walls built with blocks $B_{2}$ and $B_{1}$. t-test was applied to determine whether there is a difference in the wall compressive strength average result at a level of significance of $5 \%$ and considering the use or not of the mid height bond beam and the type of mortar bedding. The comparison was conducted between:

- Hollow walls built with concrete blocks with full bed mortar joints and with a mid-height bond beam: PB1-O-AT-CT;

- Hollow walls built with concrete blocks with full bed mortar joint and without a mid-height bond beam: PB1-O-AT.

Three specimens were tested to the axial compressive strength for each type of walls. Based on the t-test results, it was determined that $t_{4 ; 5 \%}=2.132>t=0.049$. Therefore, there is no significant difference between the average compression strength between PB1O-AT-CT and PB1-O-AT.

The same analysis, t-test, was performed for the walls built with blocks B2. Based on the t-test results it was determined that $\mathrm{t}_{4 ; 5 \%}=$ $2.132<t=6.67$. So, there is also no difference between the mean average compressive strength of PB2-the-AT-CT and PB2-the-AP. Therefore, the type of mortar bedding and the presence or not of a mid-height bond beam did not affected the wall strength.

\section{Table 17}

Testing strength and strength ratio summary

\begin{tabular}{|c|c|c|c|c|c|c|c|c|}
\hline \multirow{2}{*}{$\begin{array}{c}\mathrm{f}_{\mathrm{b}} \\
(\mathrm{MPa})\end{array}$} & \multicolumn{2}{|c|}{$f_{p}(\mathrm{MPa})$} & \multirow{2}{*}{ Wall } & \multicolumn{2}{|c|}{ Hollow wall } & \multicolumn{2}{|c|}{ Grouted wall } & \multirow{2}{*}{$\begin{array}{c}\text { Grouted/ } \\
\text { hollow }\end{array}$} \\
\hline & Hollow & Grouted & & $f(M P a)$ & $f / f_{p}$ & $f(M P a)$ & $f / f_{p}$ & \\
\hline \multirow{2}{*}{18.7} & \multirow{2}{*}{10} & \multirow{2}{*}{22.3} & B1-O/G-AT-CT & 7.8 & 0.8 & 11.53 & 0.5 & 1.5 \\
\hline & & & B1-O-AP & 7.8 & 0.8 & - & - & - \\
\hline \multirow{2}{*}{27.3} & \multirow{2}{*}{13.3} & \multirow{2}{*}{29} & B2-O/G-AT-CT & 10.7 & 0.8 & 19.79 & 0.7 & 1.9 \\
\hline & & & B2-O-AP & 11.8 & 0.9 & - & - & - \\
\hline \multirow{3}{*}{34.5} & \multirow{3}{*}{16.9} & \multirow{3}{*}{32.2} & B3-O/G-AT-CT & 11.4 & 0.7 & 18.98 & 0.6 & 1.7 \\
\hline & & & B3-O-AT & 11.8 & 0.7 & - & - & - \\
\hline & & & B3-G-AP & 11.1 & 0.7 & - & - & - \\
\hline
\end{tabular}




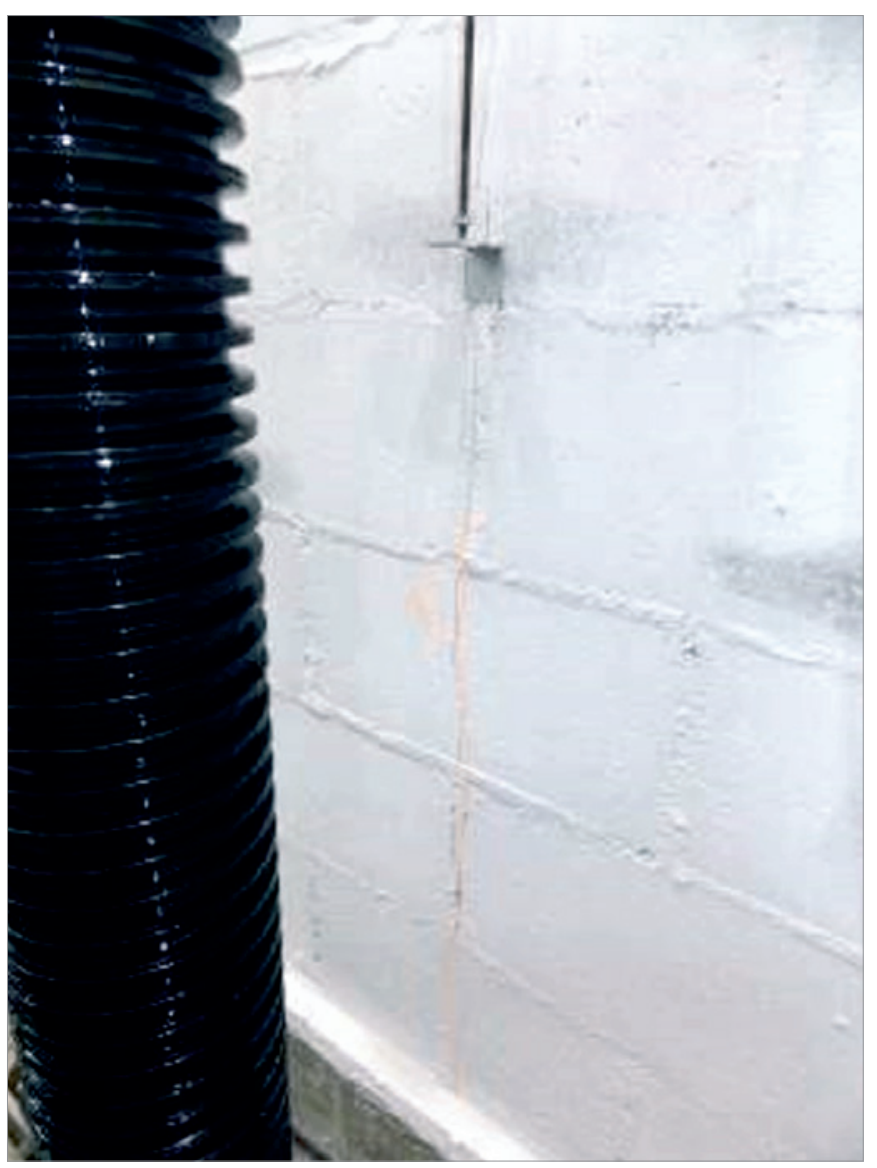

Figure 31

Grouted wall failure

\section{Conclusions}

This paper presented a comprehensive experimental program with the objective of assessing the compressive behavior of masonry with high-strength concrete block in ungrouted and grouted walls. Nominal resistance of blocks was 16,24 , and $30 \mathrm{MPa}$. The grout was produced with shrinkage compensating admixture. Walls compressive strength was evaluated considering the compressive strength of blocks, the mortar bedding type, and the use of not of a mid-height grouted bond beam.

The main conclusions of the research presented here are:

- There was no statistically significant difference between the average compressive strength for the hollow walls with full bed or face-shell bed mortar joints.

- There was no statistically significant difference between the average compressive strength for the hollow walls with full bed or face-shell bed mortar joints with and without a grouted midheight bond beam;

- All the hollow walls presented wall to prism strength ratio of 0.7 ;

- All the grouted walls showed an increase in compressive strength of at least $50 \%$ compared to hollow walls;

- The stress-strain graphs show brittle fracture of all walls with strain at failure between 0.10 and $0.15 \%$ (axial compression);

- The results of the modulus of elasticity were all greater than

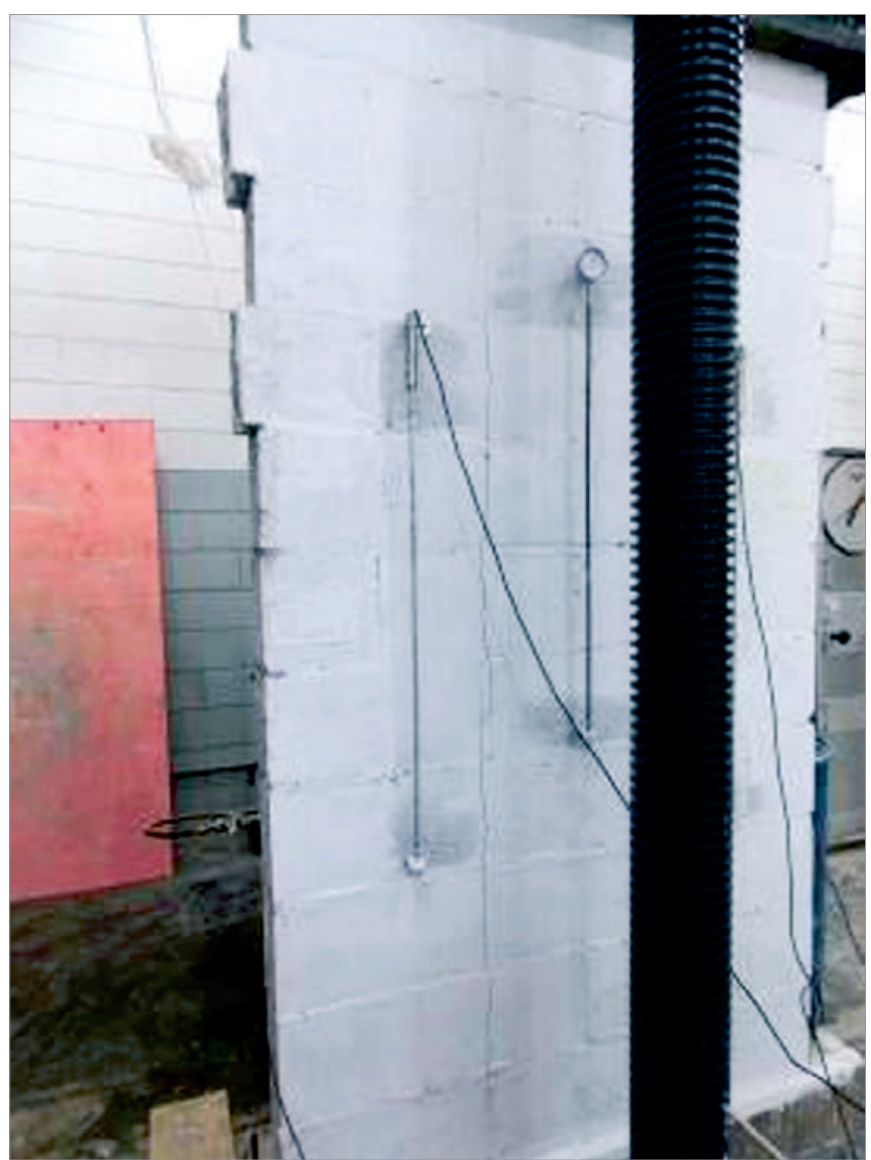

$800 f_{p}$ for hollow walls and between 688 and $848 f_{p}$ for grouted walls. Several results were above the limit of $16 \mathrm{GPa}$ specified in ABNT NBR 15961-1.

From these observations, for masonry with blocks of strength greater than $16 \mathrm{MPa}$ the following is applicable:

- The value of the wall to prism strength ratio equal to 0.7 can be adopted for high-strength concrete blocks for non-grouted hollow walls;

- For fully grouted walls the designer can consider an increase of $50 \%$ in wall strength when compared to the ungrouted wall strength;

- Considering the block geometry used, the use of mortar over the block web shell is not efficient. The recommendation is to consider mortar only on the face shell, both in the design as in the construction. Other block geometries, with vertical alignment of block webs, can produce different results than those reported herein;

- The placement of a mid-height bond block beam in the walls leads to no decreased in compressive strength;

- The value of the modulus of elasticity specified in the Brazilian standards equal to $800 \mathrm{f}_{\mathrm{pk}}$ can be benchmarked to ungrouted hollow walls but a lower value was verified for grouted walls. This is a preliminary result that needs further verification is recommended to adopt the value of $E=600$ to $650 \mathrm{f}_{\mathrm{pk}}$ for 
high-strength concrete blocks masonry (greater than $16 \mathrm{MPa}$ ); - On the other hand, the limit value for $\mathrm{E}=16 \mathrm{GPa}$. has not been verified in the results presented herein. Therefore, it is recommended that this limit be eliminated from the Brazilian standards.

\section{Acknowledgement}

The authors gratefully acknowledge the support of the Research Support Foundation of the State of São Paulo (FAPESP). grant 2012/22454-0 and 2015/02362-2, CESP- São Paulo State Energy Company and the Group Chimica Edile.

\section{References}

[1] Parsekian. G. A. Hamid. A. A. and Drysdale. R. G. Comportamento e Dimensionamento de Alvenaria Estrutural. EdUFSCar. São Carlos. S.P. Brazil. 2012.

[2] Hendry. A. W.; Sinha B. P.; Davies S. R. Design of Masonry Structures. Department of Civil Engineering. University of Edinburgh. UK. E \& FN SPON. $3^{a}$ ed. London. 2004.

[3] Curtin. W. G. Shaw. G. and Beck. J. K. Design of Reinforced and Prestressed Masonry. Thomas Telford. London. Ed. 1988.

[4] ABNT-NBR 15961-1: Alvenaria estrutural - Blocos de concreto - Parte 1: Projeto. Rio de Janeiro. 2011.

[5] ABNT-NBR 8949: Paredes de alvenaria estrutural - Ensaio à compressão simples. Rio de Janeiro. 1985.

[6] ABNT-NBR 12118: Blocos Vasados de Concreto Simples para Alvenaria - Métodos de ensaio - NBR 12118. Associação Brasileira de Normas Técnicas. Rio de Janeiro. R.J. Brazil. 2011.

[7] ABNT-NBR 5738: Concreto - procedimento para moldagem e cura de corpos-de-prova cilíndricos ou prismáticos - método de ensaio. Associação Brasileira de Normas Técnicas. Rio de Janeiro. R.J. Brasil. 2003.

[8] ABNT-NBR 7211: Agregados para concreto - Especificação. Associação Brasileira de Normas Técnicas. Rio de Janeiro. R.J. Brasil. 2009.

[9] ABNT-NBR 13279: Argamassa para assentamento e revestimento de paredes e tetos - Determinação da resistência a tração na flexão e a compressão. Associação Brasileira de Normas Técnicas. Rio de Janeiro. R.J. Brasil. 2005.

[10] Eurocode 6. 1996-1-1: Rules for reinforced and unreinforced masonry. 1996.

[11] McNary. W. S. and Abrams. D. P. (1985). Mechanics of masonry in compression. Journal of Structural Engineering. 111(4). 857-870. DOI:10.1061/(ASCE)0733-445(1985)111:4(857)

[12] Atkinson. R. H.; Noland. J. L.; Abrams. D.P. and McNary S. A deformation failure theory for stack-bond brick masonry prisms in compression. Proc. 3rd NAMC. Arlington. Texas 1985.

[13] Drysdale. R.G. Hamid. A.A. and Baker. L.R. Masonry structures: behavior and design. Prentice-Hall Inc. Englewood Cliffs. N.J. 1994

[14] Cavalheiro. O. P.; Gomes. N. S. Alvenaria estrutural de blocos vazados: resultados de ensaios de elementos e redutores de Strength à compressão. In: XXX Jornadas SulAmericanas de Engenharia Estrutural. 2002. Brasília. DF. Anais da XXX Jornadas Sul-Americanas de Engenharia Estrutural. 2002.
[15] Aly. V. L. C. Determinação da capacidade resistente do elemento parede de alvenaria armada de blocos de concreto submetido a esforços de compressão. São Paulo. 1991.103p. Dissertação (Mestrado) - Escola Politécnica. Universidade de São Paulo.

[16] Medeiros. J. S. Alvenaria estrutural não armada de blocos de concreto: produção de componentes e parâmetros de projeto. São Paulo. 1993. 2v. Dissertação (Mestrado) - Escola Politécnica. Universidade de São Paulo.

[17] Mendes. J. R. K. Resistência a compressão de alvenaria de blocos cerâmicos estruturais. Florianópolis. 1998. 185p. Dissertação (Mestrado). Universidade Federal de Santa Catarina.

[18] Mohamad. G. Comportamento mecânico na ruptura de prismas de blocos de concreto. Florianópolis. 1998. 117p. Dissertação (Mestrado). Universidade Federal de Santa Catarina.

[19] Romagna. R. H. Resistência a compressão de prismas de blocos de concreto grauteados e não grauteados. MS thesis. Universidade Federal de Santa Catarina. Florianópolis. S.C. Brazil. 2000.

[20] Maurício. R. M., Estudo teórico e experimental das ligações diretas contra-fiadas entre paredes de blocos de concreto em escala real e reduzida 1:4. Dissertação (mestrado). Faculdade de Engenharia de Ilha Solteira. UNESP. 2005.

[21] Fortes. E. S., Influência do Capeamento e Caracterização da Resistência a Compressão de Alvenaria Estrutural de Blocos de concreto. Dissertation (MS) - Universidade Federal de São Carlos. São Carlos. 2012.

[22] ABNT-NBR 6136: Blocos Ocos de Concreto Simples para Alvenaria - Requisitos. Associação Brasileira de Normas Técnicas. Rio de Janeiro. R.J. Brasil. 2007.

[23] ABNT NBR 15961-2: Alvenaria estrutural - Blocos de concreto - Parte 2: Execução e controle de obras. Associação Brasileira de Normas Técnicas. Rio de Janeiro. R.J. Brasil. 2011.

[24] ABNT-NBR 5739: Ensaio à compressão de corpos-de-prova cilíndricos de concreto. Associação Brasileira de Normas Técnicas. Rio de Janeiro. R.J. Brasil. 2007.

[25] Silva. A. F. Avaliação da Strength à compressão da alvenaria estrutural. Dissertação (Mestrado em Engenharia Civil) - Faculdade de Engenharia de Ilha Solteira. Universidade Estadual Paulista. Ilha Solteira. 2007.

\section{Notation}

$\mathrm{f}_{\mathrm{b}} \cdot \mathrm{f}_{\mathrm{bk}}=$ average and characteristic compression strength of the block (MPa);

- $\mathrm{f}_{\mathrm{p}} \cdot \mathrm{f}_{\mathrm{pk}}=$ average and characteristic compression strength of the prism (MPa);

$\mathrm{f}_{\mathrm{m}} \cdot \mathrm{f}_{\mathrm{bm}}=$ average and characteristic compression strength of the mortar (MPa);

- $\mathrm{f}_{\mathrm{k}}=$ characteristic compression strength of masonry (MPa);

- $\mathrm{f}_{\mathrm{ppk}}=$ characteristic compression strength of small wall (MPa). 